\title{
Étudier la construction des dispositions sociocognitives
}

Gains transfrontaliers et frais de douanes disciplinaires

Studying the Construction of Socio-Cognitive Dispositions. The Cross-Border

Benefits and Entry Costs of Intra-Disciplinary Imports

Estudiar la construcción de disposiciones socio-cognitivas. Ganancias

transfronterizas y gastos de aduanas disciplinarias

\section{Stéphane Bonnéry}

\section{(2) OpenEdition}

\section{Journals}

Édition électronique

URL : http://journals.openedition.org/bssg/293

DOI : $10.4000 /$ bssg.293

ISSN : $2490-9424$

Éditeur

Presses universitaires de Vincennes

Référence électronique

Stéphane Bonnéry, "Étudier la construction des dispositions sociocognitives », Biens Symboliques / Symbolic Goods [En ligne], 3 | 2018, mis en ligne le 15 octobre 2018, consulté le 04 mars 2021. URL http://journals.openedition.org/bssg/293 ; DOI : https://doi.org/10.4000/bssg.293 
Étudier la construction des dispositions sociocognitives

Gains transfrontaliers et frais de douanes disciplinaires
Studying the Construction of SocioCognitive Dispositions

The Cross-Border Benefits and Entry

Costs of Intra-Disciplinary Imports

Stéphane Bonnéry

traduction | translation

Katharine Throssell

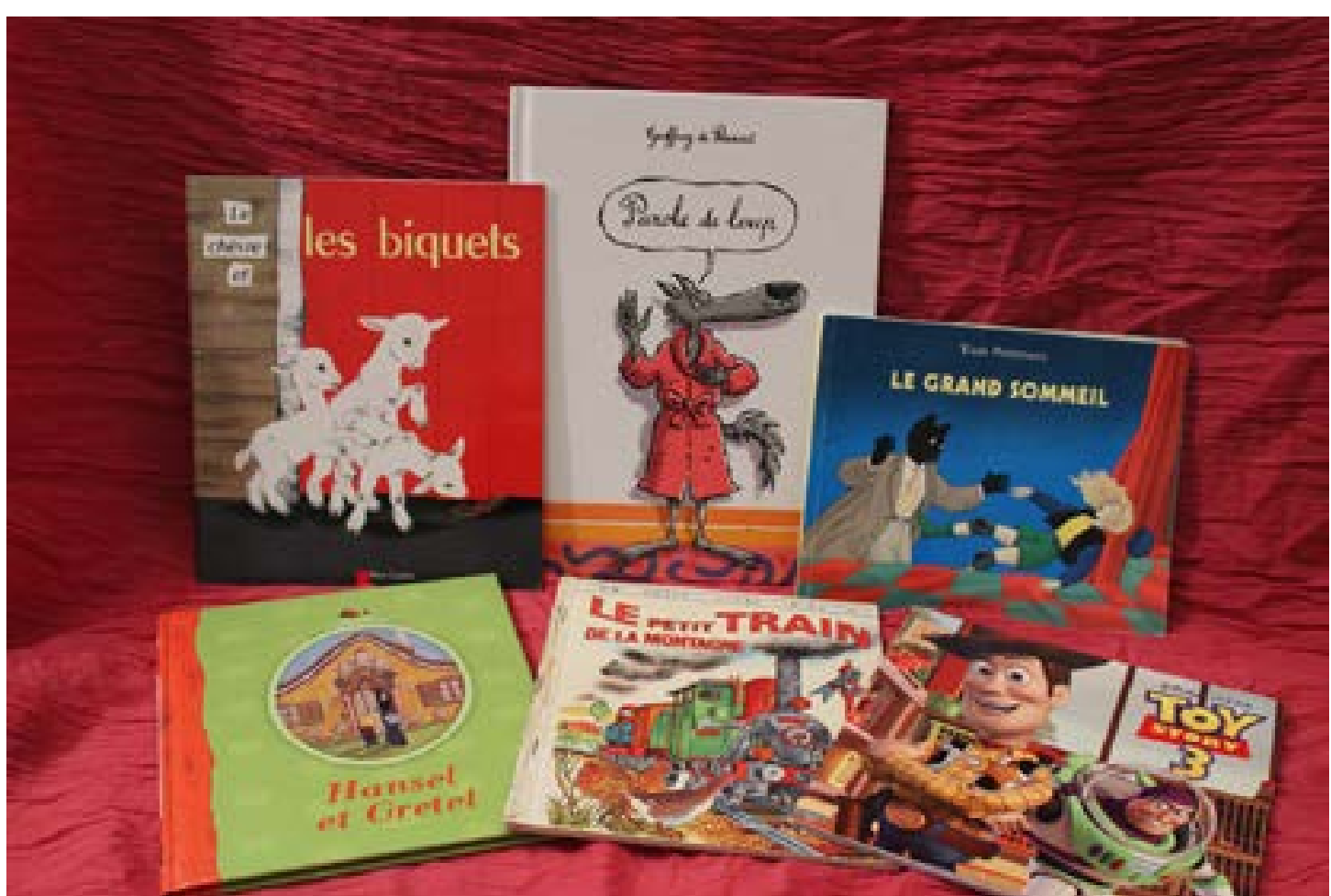

Illustration 1. Albums explicites (Toy Story, Le Petit Train de la montagne), patrimoniaux (La Chèvre et les biquets, Hansel et Gretel) et complexes (Parole de loup, Le Grand Sommei). "Simple" picture books (Toy Story, Pano the train [Le Petit Train de la montagne]), "traditional" picture books (The Wolf and the Seven Kids [La Chèvre et les biquets], Hänsel and Gretel) and "complex" picture books (Parole de loup, Le Grand Sommeil) 
Avec le développement de la sociologie et l'accumulation des connaissances, les domaines d'études de cette discipline se sont en partie spécialisés. Mais un trop grand cloisonnement conduit à ce que les sociologues de chaque domaine profitent moindrement des avancées dans les autres. Cet article montre que l'on gagne à de l'interconnaissance intradisciplinaire pour étudier la construction des dispositions « lectorales ", " scolastiques » ou " esthétiques » dans la socialisation de jeunes enfants. II expose encore les avantages que peut revêtir, pour enrichir l'approche sociologique, le fait de s'intéresser aux productions des autres disciplines qui étudient les mêmes objets, malgré les " coûts " occasionnés.

S'il est fondé sur une recherche qui a exploré les manières de lire des albums conduites conjointement par des parents et enfants (de 4 à 7 ans), notre propos ne privilégie pas l'exposition des résultats (nous renverrons vers des publications qui ont cette vocation), mais les choix théoriques qui empruntent à plusieurs sources : sociologies de l'éducation et de la culture, études littéraires et narratologiques, histoire de la littérature, et, au sein des sciences de l'éducation, didactiques et psychologie des apprentissages. Nous développerons ainsi des " services rendus » et "questions posées " par chacune de ces disciplines ou sous-disciplines aux autres, selon les formules de Mauss (à l'instar d'une discussion qui a eu lieu sporadiquement entre sociologie et psychologie - Mauss, 1924 ; Rochex, 2009) ${ }^{1}$. Ce faisant, nous insistons sur les avantages et inconvénients de cette construction d'objet à la frontière de plusieurs domaines de recherche voisins.

1 Un aspect de cette réflexion, centré uniquement sur les apports de la sociologie de l'éducation à celle de la culture, a commencé à être développé avec Florence Eloy à partir de nos recherches sur les adolescents face aux dispositifs de médiation et d'enseignement de la musique (Bonnéry \& Eloy 2017)
The development of sociology and the accumulation of knowledge in this domain have partly led to the areas of study covered by this discipline becoming more specialized. However, overcompartmentalization leads to a situation in which sociologists in each area benefit less from the advances made in others. This article shows that we can benefit from shared intra-disciplinary knowledge in studying the construction of dispositions for reading-be they "scholarly," or "aesthetic"-in the socialization of young children. It sheds light on the advantages for the sociological approach of taking an interest in the productions of other disciplines that study the same objects, in spite of the "costs" that might be incurred.

Although it is based on research that explores different ways parents share picture books with their children (of between four and seven years old), this article does not focus on the presentation of results (we will refer to other publications for this), but rather on the theoretical choices behind the study. These draw on the sociology of education and culture, literary and narrative studies, history of literature, and within education sciences, on didactics and the psychology of learning. We thus outline "services rendered" and "questions asked" for each of these disciplines and subdisciplines, following Marcel Mauss' approach (much like the sporadic discussion between sociology and psychologyMauss 1924; Rocheux 2009) ${ }^{1}$. In so doing, we will emphasize the advantages and disadvantages of constructing a research object at the intersection of several neighbouring areas of research.

1 One aspect of this reflection, solely focused on the contributions of the sociology of education to the sociology of culture, began with Florence Eloy based on our research on adolescents faced with mediation programmes and music teaching (Bonnéry \& Eloy 2017). 


\section{La construction des dispositions : un point aveugle commun aux sociologies de l'éducation et de la culture}

1.1. L'héritage des Héritiers : activités intellectuelles, dispositions à l'étude et à l'appréciation esthétique

Les risques pour la sociologie que fait courir la tendance à la parcellisation des objets d'études ont déjà été largement soulignés (Lahire 2012). L'un des arguments réside dans la perte de visibilité de ce qui se joue de transversal pour les êtres sociaux entre les différents domaines du monde social.

Les Héritiers, de Pierre Bourdieu et Jean-Claude Passeron, a consisté à décloisonner des domaines relativement distincts de la sociologie de l'époque, en particulier l'éducation, la culture et les classes sociales (Bourdieu \& Passeron 1964) ${ }^{2}$. Si la formule de " disposition " n'était pas présente dans le livre, l'une des idées centrales, soulignée par le sous-titre "Les étudiants et la culture », était que selon leur socialisation familiale dans des classes sociales différentes, les étudiants bénéficiaient pour la réussite scolaire d'un capital de connaissances culturelles plus ou moins important, de même que d'habiletés langagières inégales et d'habitudes différentes dans les manières d'appréhender les savoirs scolaires et les œuvres (comme il s'agissait surtout d'étudiants en Lettres, la question de la transposition réciproque des dispositions entre les pratiques littéraires et artistiques et les pratiques d'études

2 L'ensemble de ce paragraphe est redevable à la réflexion collective conduite dans le séminaire interlaboratoire " 50 ans après Les Héritiers », initié par Cédric Hugrée et Tristan Poullaouec, et en particulier à Claire Lemêtre avec qui nous avons organisé dans ce cadre la journée « Pédagogie rationnelle et transmission culturelle : deux héritages à revisiter ».

\section{The Construction of Dispositions: A Blind Spot Shared by the Sociology of Education and the Sociology of Culture}

1.1. The Inheritors Heritage: Intellectual Activity, Dispositions for Study, and Aesthetic Appreciation

There has already been significant discussion of the risks that the fragmentation of research objects presents for sociology (Lahire 2012). One of the arguments lies in the loss of visibility of that which is transversal for social beings between different areas of the social world.

Pierre Bourdieu and Jean-Claude Passeron's work, The Inheritors, consisted in breaking down the barriers between relatively distinct areas of sociology, as it was then, and in particular between education, culture, and social class (Bourdieu \& Passeron 1979) ${ }^{2}$ Although the term "disposition" is not present in the book itself, one of the central ideas, emphasized in the subtitle French students and their relation to culture, is that depending on their family socialization in different social classes, students have a more or less substantial capital of cultural knowledge. This cultural capital then in turn benefits them in their academic success, as do their different levels of language ability and different practices in approaching academic knowledge and texts (as these were essentially arts students, the question of the reciprocal transposition of dispositions between literary and artistic practices and the practice of university studies

2 This paragraph owes much to the collective thinking that occurred during the inter-laboratory seminar entitled " 50 ans après Les Héritiers" "The Inheritors 50 Years On"), initiated by Cédric Hugrée and Tristan Poullaouec, and in particular to Claire Lemêtre, with whom we organized a study day as part of this seminar, entitled "Relational Pedagogy and Cultural Transmission: Two Heritages to be Revised". 
universitaires était particulièrement pertinente) ${ }^{3}$. Cette idée est à la base de la recherche que nous avons conduite, tant dans les continuités que dans les différences avec elle.

Avant cette recherche, à l'instar des travaux de notre équipe ${ }^{4}$, nous avons consacré plusieurs enquêtes aux dispositions manifestées par les élèves à l'école élémentaire et au collège, en détaillant, plus que ce n'était le cas dans Les Héritiers, les activités sociocognitives (Bautier \& Rochex 1997) que conduisent les élèves, en comparaison avec celles qui sont requises par les apprentissages scolaires. II s'agissait d'éviter une tendance, fréquente en sociologie de l'éducation, à insister surtout « sur la transmission des valeurs au détriment des apprentissages intellectuels " (Chamboredon 1985 : 87). Les recherches de notre équipe font ainsi le constat que les modalités pédagogiques les plus fréquentes aujourd'hui, que leurs promoteurs revendiquent comme plus « actives » et en rupture avec le cours magistral, reposent autant que ce dernier sur l'implicite, caractéristique du cours magistral mise en évidence par Bourdieu et Passeron. Ces pratiques pédagogiques courantes dans le contexte actuel de l'école unique et de l'enseignement secondaire massifié ne créent donc pas les conditions pour que tous les élèves s'approprient les exigences scolaires. Nos recherches concluent donc que les élèves qui apprennent malgré le faible guidage pédagogique par l'école le doivent probablement aux dispositions construites dans la famille (Bautier \& Rayou 2009 ; Bonnéry 2007 ; Rochex \& Crinon 2011). On retrouve alors pleinement, pour des élèves plus jeunes que les étudiants, l'hypothèse avancée par Bourdieu et Passeron : l'inégale réussite scolaire s'explique par la présence ou l'absence, selon les types sociaux d'élèves, des

3 Les Héritiers concentre les éléments que l'on ne retrouve pas toujours aussi exhaustivement articulés dans les autres textes de la période.

4 Équipe CIRCEFT-ESCOL. was particularly relevant) ${ }^{3}$. This idea is at the heart of the research conducted here, both in the ways it continues this idea, and in its departures from it.

Prior to this investigation, in keeping with the focus of our research team ${ }^{4}$, we dedicated several studies to the dispositions demonstrated by students at primary school and lower secondary school, detailing (more than was done in the case of The Inheritors) socio-cognitive activities (Bautier \& Rochex 1997) carried out by students, in comparison with those required for academic learning. The key here was to avoid a tendency, frequent in the sociology of education, which consists in emphasizing above all "the transmission of values, to the detriment of intellectual learning" (Chamboderon 1985:87). The research conducted by our team thus observes that the most common pedagogical methods today, which are promoted as being more "active" and as breaking away from the traditional lecturing approach, in fact rely just as much as the latter on what is implicit-a characteristic of the lecture-style classroom highlighted by Bourdieu and Passeron. These teaching methods, which are frequent in the current context of the single unified school in France and mass secondary education, therefore do not create the conditions needed for all students to appropriate academic requirements. Our research thus concludes that students who learn in spite of the low levels of pedagogical guidance provided by schools, probably do so because of dispositions constructed in the family environment (Bautier \& Rayou 2009; Bonnéry 2007; Rochex \& Crinon 2011). For secondary school students, we thus fully confirm the hypothesis put forward by Bourdieu and Passeron: unequal levels of educational success can be explained by the presence

3 The Inheritors brings together elements that are not always as comprehensively articulated in other texts of the period.

4 Team CIRCEFT-ESCOL. 
dispositions requises par l'École mais dont la construction est peu prise en charge par celle-ci. Mais ces résultats se heurtent à la même limite que ceux formulés depuis Les Héritiers jusqu'à la plupart des travaux récents en sociologie de l'éducation : on postule que ces dispositions « scolairement rentables " découlent des socialisations familiales différentes sans que des recherches dans les familles aient vérifié en quoi consiste cette socialisation intellectuelle permettant de les construire. II y a des exceptions notables telles que l'attention à la présence de " jeux éducatifs " dans les familles (Lienard \& Servais 1976), ou des travaux sur les socialisations langagières (Bernstein 1975), sans oublier l'usage de l'écriture et de la lecture (Lahire 1993, 1995) ou la réalisation des devoirs (Kakpo 2012) dans les familles populaires. Mais un inventaire montre que les enquêtes sur la socialisation familiale sont peu nombreuses (Darmon 2010 : 37). De plus, la plupart d'entre elles privilégient la transmission de valeurs et de goûts, et rarement les manières précises d'habituer à des activités cognitives différentes selon les groupes sociaux. Or, notre objectif d'expliquer ce qui construit la réussite scolaire et l'appréciation «cultivée » de l'art nécessite d'entrer davantage dans le détail en se focalisant sur les activités cognitives.

Si l'on envisage maintenant la continuité des travaux conduits autour de Bourdieu sur les pratiques culturelles, Les Héritiers constitue également un acte initiateur de l'intérêt pour les schèmes de perception des œuvres qui sont mobilisés dans l'appréciation artistique, en même temps que pour une analyse du " code culturel " dont l'activation est sollicitée par l'œuvre chez le spectateur averti. Si des écrits ultérieurs portant spécifiquement sur le champ culturel, notamment La Distinction, complètent l'approche en envisageant également les réceptions «par corps ", Les Héritiers présente l'intérêt d'étudier la question du transfert de dispositions entre milieux de socialisation (famille, or absence (depending on the social situation of students) of the dispositions that are required by school, but not primarily taught there. However, these results run up against the same limitations as those that have been formulated since The Inheritors, and which are found in most recent studies in the sociology of education. There is an assumption that these "academically profitable" dispositions result from different family socializations, without research into the family environment having verified what this socialization might consist of. There are notable exceptions, however, such as the focus on the presence of "educational games" in families (Lienard \& Servais 1976), or studies on language socialization (Bernstein 1975 ), without overlooking the use of reading and writing (Lahire 1993, 1995), or the completion of homework (Kakpo 2012) in working-class families. However, an inventory shows that studies on family socialization are few and far between (Darmon 2010:37). Moreover, most focus on the transmission of values and tastes, and rarely on the specific ways of familiarizing children with different cognitive activities according to their social group. Our objective of explaining what builds academic success and a "cultivated" appreciation of art, requires us to engage more closely by focusing on cognitive activities.

If we now consider the continuity of studies conducted on cultural practices, under the influence of Bourdieu, The Inheritors also represents a starting point for a focus on the schemata of perception that are mobilized in artistic appreciation, as well as on analysis of the "cultural code" which the book solicits from the informed spectator. Although later studies have specifically addressed the cultural field, Distinction in particular, and compliment the approach by also considering reception "by/through the body" The Inheritors has the advantage of studying the question of the transfer of dispositions between spheres of socialization (family, school, leisure activities) with regard to "legitimate" works that mobilize an 
scolarité et pratiques de loisirs) au sujet d'œuvres "légitimes 》 qui mobilisent une disposition " esthétique » (Bourdieu 1979) ou une disposition "scolastique " (Bourdieu 1997). Dans cette voie, si notre recherche s'est aussi intéressée aux appropriations des albums pour enfants qui sont éloignées des pratiques valorisées par les enseignants et les bibliothécaires, l'enquête a privilégié les socialisations à des activités intellectuelles qui participent de l'appréciation " esthétique » ou " savante », pour comprendre ce qui est transposable de la socialisation familiale aux pratiques scolaires ou culturelles.

\section{2. Étudier la construction des dispositions}

Avant même d'envisager la spécificité des dispositions « intellectuelles », nous sommes donc devant une double question : comment analyser des « dispositions » et comment étudier leur construction?

La notion de disposition est une métaphore de ce qui a été intériorisé dans la socialisation et que l'individu concerné est enclin à activer dans certains types de situations. Une disposition est donc inobservable directement. Mais on peut d'abord recueillir des manières d'être, de faire et de penser suffisamment récurrentes face à des types de contextes identiques pour permettre de dire qu'il s'agit d'une manifestation d'une disposition à réagir face à une classe de situations. Et, en amont de son activation, on peut identifier des conditions de socialisation qui semblent favorables à la constitution de cette disposition (Lahire 2002 : 18-24). Sur ce dernier point, deux grandes options se présentent. Soit - c'est plus rarement fait - étudier auprès d'enfants ce que nous appelons la socialisation " en train de se faire ». Soit - comme le font le plus souvent les études - s'intéresser à des dispositions déjà constituées, et reconstituer rétrospectivement la socialisation qui permet d'expliquer les comportements récurrents d'un adulte. "aesthetic" (Bourdieu 1984) or a "scholastic" disposition (Bourdieu 2000). From this perspective, although our research also looked at the appropriations of picture books that do not conform to the practices valued by teachers and librarians, it focused on socialization to intellectual activities that participate in "aesthetic" or "intellectual" forms of appreciation, in order to understand what can be transposed from family socialization to academic or cultural practices.

\subsection{Studying the Construction of Dispositions}

Before even considering the specificity of "intellectual" dispositions, we are therefore faced with a dual question: how can we analyse these "dispositions" and how can we study their construction?

The notion of disposition is a metaphor for what has been internalized through socialization and which the individual is inclined to activate in certain types of situation. It is therefore impossible to observe a disposition directly. However, we can begin by recording ways of being, doing, and thinking in identical contexts that are sufficiently frequent to surmise that they are manifestations of a disposition to react in a certain type of situation. Indeed, we can identify the socialization conditions that seem favourable to the development of this disposition prior to its activation (Lahire 2002: 18-24). There are two major options here. Either-as is more rarely the casewe can study children to see "socialization as it happens" (en train de se faire), or-as is more common-we can look at dispositions that are already established and retrospectively reconstruct the socialization that allows us to explain recurring behaviour in adulthood. 
Telle était déjà la perspective des Héritiers, où l'enquête portait sur des étudiants, donc de jeunes adultes (Bourdieu \& Passeron 1964), et de L'Amour de l'art, fondé sur une étude des visiteurs de musées adultes ou, au moins, de lycéens (Bourdieu, Darbel, Schnapper 1969). Le constat était fait que la réussite universitaire dans les filières littéraires et la fréquentation des musées d'art se renforçaient mutuellement, et qu'elles s'expliquaient surtout par la socialisation enfantine dans la famille. Mais les modalités de cette socialisation primaire n'étaient explorées que via les souvenirs des

enquêtés

Or il nous semble que le souvenir des enquêtés sur leur enfance donne trop partiellement accès aux conditions de socialisation auxquelles ils ont été confrontés, car les mécanismes de socialisation (comme l'ensemble de leurs pratiques) échappent souvent à la conscience aussi bien de ceux qui socialisent que de ceux qui sont socialisés. La même remarque vaut pour les écrits ultérieurs de Bourdieu qui systématisent la théorie de la légitimité culturelle : si cette dernière décrit les goûts des adultes comme le résultat de leur socialisation familiale et scolaire, elle fait de cette socialisation un point aveugle, dont l'analyse requerrait un travail

spécifique :

II appartiendrait à une sociologie génétique d'établir comment se constitue ce sens des possibilités et des impossibilités, des proximités et des distances. (Bourdieu $1979: 545)$

Sans prétendre développer un tel programme d'étude d'une diversité de dispositions, c'est néanmoins dans cette perspective que nous avons cherché à comprendre la construction d'un type précis de disposition, à savoir celle qui facilite l'appropriation des savoirs scolaires et porte à l'appréciation esthétique des œuvres. II s'agit
This was the perspective adopted in The Inheritors, where the study began with young adults at university (Bourdieu \& Passeron 1979), and The Love of Art, which was based on a study of adult (or at least adolescent) visitors to museums (Bourdieu, Darbel, Schnapper 1991). They observed that university success in arts degrees and attendance of museums mutually reinforced one another, and that they were above all explained by childhood socialization in the family. However, the modalities of this primary socialization were only explored through the memories of the interviewees.

It seems to us that interviewees' memories of childhood give insufficiently complete access to the conditions of socialization encountered, since the mechanisms of socialization (just like all other experiences) often occur outside the awareness of both those who socialize and those who are socialized. This is also true for Bourdieu's later works that systematize the theory of "cultural legitimacy." Although the latter describes adult tastes as the result of family and school socialization, it turns this socialization into a blind spot, the analysis of which would require specific study:

It would be the task of a genetic sociology to establish how this sense of possibilities and impossibilities, proximities and distances is constituted. (Bourdieu 1984: 596)

We do not claim to develop such a programme to study the diversity of dispositions, however it is from this perspective that we have attempted to understand the construction of a specific type of disposition, that which facilitates the appropriation of academic knowledge and leads to the aesthetic appreciation of art. This is 
de comprendre ce qui permet de « construire » ces dispositions, et donc « d'incorporer » des habitudes « intellectuelles »

On n'incorpore pas exclusivement du « corporel », et les catégories de pensée, les « structures cognitives », les « schèmes de perception et d'appréciation » [...], tout ce qui constitue les lunettes au travers desquelles nous envisageons le monde social, sont eux aussi « incorporés » lors du processus de socialisation, tout prêts à être activés par les situations et les expériences. (Darmon 2010 : 19)

Pour étudier la construction « en train de se faire » des dispositions, la distinction qu'opère Bernard Lahire de trois modalités de socialisation a été heuristique (Lahire 2002 : 420-422). Nous ne parlerons pas ici de la première, socialisation par inculcation de croyances ou de valeurs, car elle n'a été prise en compte qu'à la marge, à propos de la transmission des goûts pour des thèmes traités par les albums ou pour des histoires qui « ont une morale », etc. Les deux autres modalités ont davantage été utilisées.

D'abord, la socialisation peut s'effectuer de façon « indirecte » ou «silencieuse » (id.). Dans notre recherche sur les usages des albums de « littérature de jeunesse ${ }^{5}$, le contexte qui produit des conditions de socialisation est notamment constitué par l'ampleur et le contenu des bibliothèques domestiques que nous avons étudiées. Bien entendu, les parents sont pour beaucoup dans cette socialisation, mais leur intervention est bien ici « indirecte ». Le terme semble d'autant plus approprié que les albums ont été

5 Cette expression s'est imposée dans le champ de l'édition pour enfants, nous la reprenons pour désigner ce domaine de la production de livres, et non pour trancher sur la pertinence ou non de lui conférer le statut de littérature, pas plus que sur l'existence ou non d'un domaine spécialisé pour le lectorat enfantin et juvénile. a matter of understanding what enables the "construction" of the dispositions and thus the "incorporation" of "intellectual" practices:

We do not only incorporate the "corporeal," and the thought categories, "cognitive structures" and "patterns of perception and appreciation" [...], everything that constitutes the glasses through which we envisage the social world are also "incorporated" during the socialisation process, ready to be activated by situations and experiences. (Darmon 2010: 19)

Bernard Lahire's distinction between three modalities of socialization is heuristic in studying the construction of dispositions "as it happens" (Lahire 2002: 420-422). We will not discuss the first of these modalities here, (socialization through the inculcation of beliefs and values), because it has only been marginally taken into account in terms of the transmission of preferences for the themes covered by picture books or for "moral" tales, and so forth. We draw more substantially on the two others.

Firstly, socialization may occur "indirectly" or "silently" (Lahire 2002). In our research on the use of picture books, the context that produces the conditions for socialization is in particular influenced by the size and content of the home libraries that we studied. Of course, parents have a significant role in socialization, but their intervention is indeed "indirect" here. The term seems all the more appropriate given that picture books have been considered as "instruments of socialization" (Chamboredon 1985) in the sense that their regular reading familiarizes children with encountering certain narrative structures rather than others. 
considérés comme « instruments de socialisation » (Chamboredon 1985) au sens où leur fréquentation régulière habitue par exemple à rencontrer certaines structures narratives plutôt que d'autres.

La socialisation peut également être « directe » lorsqu'elle passe par des actions conjointes. Dans notre recherche, il s'agit de la lecture partagée d'albums qui englobe l'oralisation du texte (par l'adulte), la désignation d'éléments dans les images (verbalement ou gestuellement, par l'adulte ou l'enfant), complétées ou non de commentaires et d'anticipations sur la suite de l'histoire (par exemple lorsqu'un enfant est face à un livre à structure répétitive),

l'encouragement à adopter telle posture de lecteur, etc.

\section{3. Étudier les activités qui forgent une disposition}

Mais comment prélever dans une situation observée ce qui semble participer d'une disposition particulière, à savoir la disposition à lire de manière relativement conforme aux attentes des institutions scolaires et culturelles ?

Dans l'observation de lectures conjointes, nous avons focalisé l'attention sur tous les actes qui sollicitent, encouragent, accompagnent ou réfrènent la mobilisation chez l'enfant d'une ou plusieurs activités cognitives. En réalité, nous ne pouvons prétendre montrer exhaustivement ce qui construit une disposition esthétique ou lectorale. En revanche, de façon plus détaillée, nous allons mettre au jour des manières de faire des adultes qui, si elles sont répétées, peuvent être considérées comme favorisant la constitution d'habitudes à mettre en œuvre des activités cognitives qui elles-mêmes concourent à la fabrication de cette disposition. Cette question du niveau de détail de l'action de socialisation est déterminante des choix de problématisation.
Socialization can also be "direct" when it operates through joint action. In our research, this occurs in the shared reading of picture books, including vocalization of the text (by the adult) and the designation of elements in the images (verbally or gesturally, by the adult or child), complemented or not by comments or anticipation of what is to come in the story (in the case of a repetitive structure, for example), encouragement to adopt a particular position as a reader, and so forth.

\subsection{Studying Activities that Forge a Disposition}

How can we identify the elements that participate in the development of a particular disposition-in this case the disposition to read in a way that is relatively consistent with the expectations of academic and cultural institutions?

In our observation of shared reading practices, we focused our attention on all the actions that solicited, encouraged, accompanied, or restricted the mobilization of one or several cognitive activities in the child. In reality, we cannot claim to exhaustively demonstrate what constructs a disposition for reading or aesthetic appreciation. However, we will carry out a more detailed exploration of the approaches of adults, which-if they are regular-may be seen as encouraging the development of habits to mobilize cognitive activities that themselves contribute to the construction of this disposition. This question of the level of detail in the action of socialization plays a crucial role in the choices involved in developing our research question. 
En effet, produire des analyses au niveau un peu global de la " disposition » est suffisant pour des recherches qui ont besoin de faire correspondre des attitudes récurrentes (observées chez des adultes notamment) à des origines socio-culturelles. Mais il nous semble utile d'entrer davantage dans le détail quand on vise à comprendre comment se constituent des inclinations à percevoir, penser et agir de telle ou telle manière face à un type de situations que l'on étudie spécifiquement, et donc de s'intéresser précisément aux activités cognitives ${ }^{6}$ qui sous-tendent la disposition « lectorale »

(Renard 2011).

Ce choix encourt fatalement le risque d'être taxé de légitimisme, et il représente donc un « coût transfrontalier » d'être moins compris d'un domaine à l'autre de la sociologie. De fait, nous accordons moins d'intérêt à l'appropriation hétérodoxe des objets légitimes alors qu'il est courant de le faire en sociologie de la culture, ou plutôt nous la considérons essentiellement au regard de l'écart avec les réceptions les plus valorisées par les institutions éducatives et culturelles. Mais ce choix permet d'étudier de façon plus détaillée ce qui structure les dispositions au goût distingué, à savoir les activités socio-cognitives précises qui participent de l'approche «formelle » propres à la disposition « esthétique » ou au raisonnement « scolastique » (Bourdieu 1979 : 29 ; Bourdieu 1997 ; Eloy 2015) : savoir identifier dans l'image ou le texte un indice signifiant, interpréter et formuler un non-dit, inférer une signification, déduire une morale ou formuler une conclusion ouverte, commenter une œuvre à partir de ses points communs et différences avec d'autres œuvres, selon l'auteur, l'éditeur, etc.

6 Pour l'étude de dispositions à agir physiquement, il serait ainsi opportun d'explorer les activités corporelles qui les construisent ainsi que les éventuels discours qui les accompagnent (par exemple « être courageux » pour tenir face aux efforts physiques)
Indeed, conducting analysis at the overarching level of the "disposition" is sufficient for research that needs to associate recurring attitudes (observed among adults, in particular) with socio-cultural backgrounds. However, it seems useful to take a more detailed approach if we aim to understand the construction of inclinations to perceive, think, and act in a particular way, in light of the specific type of situation we are studying. It is therefore important to focus on the cognitive activities 5 that underlie "reading" dispositions (Renard 2011)

This choice necessarily opens us up to possible accusations of legitimism, and it therefore represents a "cross-border cost" of being less well understood from one area of sociology to another. Indeed, we are less interested in the heterodox appropriation of legitimate objects, although this is common in the sociology of culture, or rather we essentially consider this in light of its distance from the receptions that are valued by cultural and educational institutions. This choice allows us, however, to conduct a close analysis of the forces that structure dispositions for distinguished taste, in particular the specific socio-cognitive activities that contribute to the "formal" approach to the "aesthetic" disposition or "scholastic" reasoning (Bourdieu 1984: 21; Bourdieu 2000; Eloy 2015). These include being able to identify a significant clue in a text or image, interpret or formulate something left unsaid, infer meaning, deduce a moral or formulate an open conclusion, comment upon a work based on its similarities and differences from other works, depending on the author, or the editor etc.

5 For the study of dispositions for physical action, it would be appropriate to explore physical activities that construct them, as well as the discourses that might accompany them (for example "being brave" in the face of physical effort) 
Cette approche nous semble complémentaire des orientations les plus fréquentes en sociologie des pratiques culturelles qui, depuis l'autonomisation relative de ce sous-domaine disciplinaire, a moins exploré les activités cognitives ou schèmes de perception mobilisés dans l'appréciation savante des œuvres, que la question des goûts, de leur légitimité ou de leur éclectisme.

Même les exceptions notables à ce constat le confirment en partie. C'est le cas de la grande enquête de Lahire procédant par portraits d'individus et centrée sur leurs pratiques culturelles. Ce livre vise avant tout à démontrer que les profils « dissonants » (avec des pratiques de légitimité inégale) sont majoritaires par rapport aux profils consonants : les usages des œuvres légitimes sont donc étudiés principalement sous l'angle des goûts pour des répertoires plus ou moins variés selon leur légitimité. Notamment, Lahire avance que le mélange des genres est " potentiellement une nouvelle formule génératrice des pratiques et des représentations 》 (Lahire 2004/2006 : 638) conduisant à apprécier à la fois des œuvres canoniques, distinguées et populaires. II explore particulièrement "le métissage de quoi avec quoi ? " (ibid. : 651), mais moins systématiquement les activités cognitives engagées dans l'appréciation d'œuvres de légitimité variée. Pourtant, ces éléments sont présents dans plusieurs extraits d'entretiens, montrant l'inégal " intérêt pur pour la forme » de l'œuvre (Bourdieu, 1979 : 54) propre à la disposition « savante ". Par exemple la mémorisation ou non du nom des artistes par les enquêtés (Lahire 2004/2006 : 233,286 , etc.), ou celle des titres (ibid. : 279,337 , etc.), ou encore les comparaisons de versions (entre série TV et film - ibid. : 354 ; entre un livre et son adaptation en film - ibid. : 361 ; entre interprétations d'une même pièce de théâtre - ibid. : 365 ). Mais cet aspect ne fait pas l'objet d'un traitement spécifique transversal aux entretiens : l'analyse porte bien plus systématiquement sur
This approach appears complementary to the more common orientations of the sociology of cultural practices. Since this disciplinary subarea has become more autonomous, it has tended to focus less on the cognitive activities or patterns of perception mobilized in scholarly appreciations of works of art or literature, has and more on the question of tastes and their legitimacy and eclecticism.

Even the notable exceptions to this observation partly confirm it. This is the case of Lahire's major study based on portraits of individuals, focusing on their cultural practices. This book aims above all to demonstrate that the "dissonant" profiles (with practices of unequal legitimacy) in fact constitute the majority, compared with "consonant" profiles. The use of legitimate works is therefore studied primarily from the perspective of preferences for repertoires that are relatively varied in their legitimacy. In particular, Lahire argues that the combination of genres is "potentially a new formula generating practices and representation" (Lahire 2004/2006: 638) that leads to an appreciation of popular, distinguished and canonical works. He particularly explores "the mixing of what with what" (Ibid.: 651), but less systematically addresses the cognitive activities involved in the appreciation of works of different degrees of legitimacy. However, these elements are present in several interview extracts, demonstrating the unequal "pure interest in form" (Bourdieu 1984: 52) specific to the "scholarly" disposition. For example, whether or not interviewees memorize the names of artists (Lahire 2004/2006: 233,286 , etc.) or titles (Ibid.: 279,337 , etc.), or the comparison between different versions (between a television series and a film, Ibid.: 354; between a book and a film adaptation, Ibid.: 361 between stagings of a play, Ibid.: 365 ). However, this aspect is not treated systematically in all the interviews. The analysis is much more consistently directed towards the question of who listens to what (legitimate or not) rather than to who has an "aesthetic" or 
qui écoute quoi (légitime ou pas) que sur qui apprécie de façon " esthétique » ou « participative » les œuvres selon leur degré de légitimité. C'est précisément ce sur quoi nous avons au contraire voulu porter l'attention.

\subsection{Le choix de la lecture et de la tranche d'âge : étudier la} construction des dispositions lectorales

Dans cette perspective, le choix de l'activité de lecture d'albums tient à plusieurs raisons. Depuis les premiers travaux sur les dispositions en jeu dans l'appréciation culturelle chez les adultes, il apparaît que les schèmes littéraires sont dominants dans les attentes scolaires en matière de dispositions culturelles, et transposables à d'autres arts : commentaire « littéraire » du cinéma, du jazz, etc. (Bourdieu, Darbel, Schnapper, 1966 : 102). Cela explique le choix d'étudier la construction des dispositions lectorales, activables potentiellement dans d'autres pratiques culturelles, et donc les albums, mêlant textes et images, susceptibles de donner à voir des activités relevant

de la « lecture » du texte, comme de l'interprétation d'images.

De plus, la lecture jouit de l'importance qui lui a été historiquement accordée par l'école primaire, et la "littérature de jeunesse " a été introduite dans les pratiques d'enseignants depuis une cinquantaine d'années jusqu'à ce que, en 2002, des listes de références d'ouvrages soient publiées pour l'école élémentaire (listes renouvelées en 2007 et 2013), puis en 2013 pour l'école maternelle. La « littérature de jeunesse » est un champ de l'édition qui, après avoir été porté par des pédagogues et des parents, s'est progressivement autonomisé sous l'action des bibliothécaires (Chartier \& Hébrard 2000) en phase avec la demande d'instruments culturels pour l'éducation des enfants dans les nouvelles classes moyennes intellectualisées (Chamboredon \& Fabiani 1977). Mais les usages de ces livres destinés à un public jeune ne sont plus "participative" appreciation of the works, according to their degree of legitimacy. It is this point that we have chosen to focus on.

\subsection{Choice of Reading and Age Group: Studying the Construction of Dispositions for Reading}

From this perspective, the choice of activity-reading children's books - is based on several factors. Since the first studies on the dispositions involved in cultural appreciation among adults, it has been clear that literary schemas dominate academic expectations of cultural dispositions and can be transferred to other art forms"literary" commentaries on cinema, jazz, and so forth (Bourdieu, Darbel, Schnapper 1990). This explains the decision to study the construction of dispositions for reading, which can be potentially activated in other cultural practices. Picture books, which by definition combine text and image, are therefore likely to reveal activities related to "reading" a text as well as interpreting images.

Moreover, reading benefits from the importance traditionally awarded it in primary education. In France, children's literature was introduced into teaching practices fifty years ago, and in 2002 lists of recommended texts were published for primary schools (this list was renewed in 2007 and 2013), and then in 2013 for preschool education. Children's literature is a sector of publishing that, having been promoted by teachers and parents, has become progressively autonomous due to the involvement of librarians (Chartier \& Hébrard 2000) in keeping up with the demand for cultural instruments for the education of children in the new intellectual middle classes (Chamboderon \& Fabiani 1977). But the use of children's books is no longer the prerogative of families with higher levels of cultural capital. Although differences remain, children's books have become 
l'apanage des familles longuement scolarisées : même si des différences persistent, ils ont été diffusés largement, au cours des dernières décennies, dans les différents types sociaux de familles (Octobre, Détrez, Mercklé, Berthomier 2010), et notamment dès l'âge de l'école maternelle et du début de l'école élémentaire.

À cet âge-là, la lecture est donc une activité qui peut être observée dans divers milieux sociaux. Les différences à son sujet ne résident plus seulement dans l'absence ou la présence de cette pratique, mais aussi dans les modalités d'usage, notamment les activités cognitives engagées dans ces lectures.

La lecture d'albums est particulièrement pertinente pour notre recherche car des albums sont désormais conçus pour des enfants qui ne sont pas encore " déchiffreurs » de textes, au sens du code alphabétique : Iorsqu'ils sont scolarisés en moyenne ou grande section de maternelle, ou en début de CP, il est explicite pour les concepteurs des livres, comme pour les parents, que ces enfants ne sont pas autonomes pour appréhender l'ouvrage. Par conséquent, ces albums, associant textes et images, sont utilisés dans le cadre de «lectures partagées » (Grossman 1996) entre un adulte et un (ou plusieurs) enfant(s). Cette lecture conjointe, articulant et répartissant les tâches entre les co-lecteurs en matière d'oralisation du texte et de commentaire sur les images ou l'histoire, est susceptible de donner à voir une socialisation aux dispositions lectorales. Cette socialisation est bien plus difficilement observable par le chercheur lorsque les enfants plus âgés lisent les livres seuls, et qu'elle passe alors par des échanges plus diffus et disjoints du moment de " lecture ". Ce moment de pratique conjointe est donc pertinent à observer en tant que moment où des activités cognitives sont accompagnées ou obérées. II permet ainsi d'étudier la socialisation, « en train de se faire " à cet âge-là, aux activités cognitives engagées dans la lecture, et de compléter widespread in families from different socio-economic environments over recent decades (Octobre, Détrez, Mercklé, Berthomier 2010), particularly from the beginning of preschool ${ }^{6}$ and early primary.

At this age, reading is therefore an activity that can be observed in various social environments. Differences lie not only in the absence or presence of established practice, but also in the ways in which it is used, particularly in terms of the cognitive activities involved.

Picture books are particularly relevant for our research because texts are now designed for children who cannot yet "deciphering" texts, in the sense of the alphabetic code. In the second or third year of preschool, or in first-year primary (roughly between the ages of 4 and 6), both publishers and parents are explicitly aware that these children are not autonomous in accessing this material. As a result, these books, which associate images and text, are used in the context of "shared reading" (Grossman 1996) between an adult and one or several children. This shared reading, which links and distributes the roles between co-readers in terms of vocalization of the text and commentaries on the images or the story, is liable to reveal a socialization to dispositions for reading. This socialization is much more difficult for a researcher to observe when children are older and read books alone, and it occurs through more diffuse and disconnected exchanges during this reading time. Observing an instance of shared reading is therefore relevant as a moment in which cognitive activities are encouraged or hampered. It thus allows us to study socialization "as it happens" at this age, along

6 In France, preschool (école maternelle) begins at age 3 and lasts three years. 
ce que l'on en savait surtout par l'étude rétrospective chez des lycéens (Détrez 1998 ; Renard 2011) ou par celle des pratiques plus générales mobilisant l'écrit dans les familles (Lahire 1995).

\section{Une recherche entre plusieurs domaines de connaissance}

2.1. Étudier les œuvres comme instruments de socialisation indirecte : gains et coûts dans la sociologisation des apports d'autres disciplines

Avant d'étudier les formes de lecture effective mises en œuvre par les parents et les enfants, nous avons analysé les albums utilisés, car ceux-ci ne sont pas équivalents et ne sollicitent pas les mêmes activités cognitives pour accéder aux significations des œuvres. Cette recherche s'est donc inscrite dans la continuité des travaux conduits autour de Bourdieu, qui avaient considéré la confrontation avec l'œuvre comme la rencontre entre, d'une part, les codes dont l'œuvre sollicite ou rend possible l'activation, et, d'autre part, les schèmes de perception des spectateurs ou lecteurs, inégalement connivents avec ce code, le « décodage » impliquant des pré-requis culturels chez le spectateur ou lecteur. Ce sont ces pré-requis que nous avons étudiés dans le détail au sein des albums recensés dans des familles socialement contrastées, en tant qu'instruments

de socialisation indirecte à des activités cognitives différentes.

Pour ce faire, un premier corpus a été constitué par le recueil du contenu des bibliothèques domestiques à disposition d'enfants de la tranche d'âge $4 / 7$ ans. Tous les ouvrages présents au domicile (possédés ou empruntés) ont été recensés (couverture photographiée afin de les retrouver en bibliothèque pour les analyser) dans chaque famille, puis un entretien semi-directif a with the cognitive activities involved in reading, and to complement what we have learned about this through the retrospective study of high school students (Détrez 1998; Renard 2011) or through more general practices involving writing in families (Lahire 1995).

\section{Research Between Several Areas of Knowledge}

2.1. Studying Texts as Instruments for Indirect Socialization: Costs and Benefits in the Sociologization of Contributions from Other Disciplines

Before studying the forms of reading used by the parents and children, we analysed the books used, because these techniques cannot be considered equivalent and do not solicit the same cognitive activities in accessing their meanings. This research is therefore situated in the continuity of Bourdieu's approach, which considers the confrontation with the text as the encounter between the codes that the text solicits or activates on one hand, and on the other hand the readers' or spectators' patterns of perception, which are unequally adapted to those prerequisites. "Decoding" therefore requires cultural prerequisites for the reader or viewer. It is these prerequisites that we studied in detail within the children's books that we encountered in the homes of families from different social backgrounds, as instruments of indirect socialization to different cognitive activities.

In order to do this, the initial corpus was constituted by collating the content of home libraries available to 4-to 7-year-old children. All the books present in each family home (owned or borrowed) were inventoried (all the covers were photographed in order to research and analyse them later), and then a semi-directive interview was conducted with the parents relating to the choice of books, the 
été réalisé avec les parents sur les modalités de choix des livres, sur les pratiques culturelles des enfants et des adultes ainsi que sur les trajectoires scolaires, sociales et professionnelles $(\mathrm{N}=107$

familles socialement contrastées) ${ }^{7}$.

Parmi les ouvrages, les albums narratifs ont été codés ${ }^{8}$ selon la typologie suivante, élaborée dans des recherches précédentes sur les albums et leurs usages à l'école (Bonnéry 2012, 2014) : albums explicites, patrimoniaux ou complexes. Les albums " explicites " délivrent au lecteur l'essentiel de ce qui est nécessaire pour accéder au sens principal de l'histoire. Les ouvrages " patrimoniaux » (surtout les contes, mais aussi la mythologie ou les adaptations des grands classiques $\mathrm{du} \mathrm{XIX}^{\mathrm{e}}$ siècle) sont aussi explicites, mais ils se distinguent des précédents par le fait qu'ils racontent des histoires qui font référence non seulement d'une génération à l'autre, mais aussi pour comprendre les nouvelles histoires qui s'en inspirent ${ }^{9}$. Les albums « complexes » imposent au lecteur - ou au binôme adulte/enfant - de découvrir le sens du livre (ou ses sens volontairement pluriels) y compris en déjouant les « fausses pistes » tendues par l'auteur, ou les sous-entendus.

Cette typologie est inspirée de la première enquête sociologique sur les albums (Chamboredon \& Fabiani 1977), mais nous l'avons détaillée à partir de critères importés d'un état de l'art interdisciplinaire. Ainsi, un album a été considéré comme

7 L'essentiel du recueil a été réalisé par des étudiants de Paris 8, encadrés par nos soins dans des cours d'initiation à la recherche.

8 Le codage est réalisé par Véronique Soulé, spécialiste de littérature de jeunesse, dans le cadre d'une mission effectuée dans l'équipe CIRCEFTESCOL.

9 Dans ce qui suit, l'expression « ouvrage explicite » désigne donc les livres qui ont été codés comme tels, excluant les ouvrages qui sont à la fois patrimoniaux et explicites, et qui seront nommés « patrimoniaux » par souci de raccourci. Un même livre est codé dans une seule des trois catégories. cultural practices of children and adults, as well as their social, educational, and professional trajectories $(\mathrm{N}=107$ families from diverse social backgrounds) ${ }^{7}$.

Among the texts, the narrative picture books were $\operatorname{coded}^{8}$ according to the following typology, developed in previous research on children's books and their uses in the school environment (Bonnéry 2012, 2014): simple, traditional, or complex texts. "Simple" picture books provide the reader with everything necessary to access the primary meaning of the story. "Traditional" books (particularly fairy tales, but also mythology, or adaptations of nineteenthcentury classics) are also simple but are distinguished from the previous category by the fact that they tell stories that are not merely recognized from one generation to the next, but which are also necessary for understanding new stories inspired by them ${ }^{9}$. "Complex" picture books ask the reader-or the adult/child pairto discover the meaning of the book (or its intentionally plural meanings), which can include avoiding the author's "red herrings" or double meanings.

This typology is inspired by the first sociological enquiry into picture books (Chamboderon \& Fabiani 1977), but it has been refined

7 Most of the data collection was conducted by students at University Paris 8 , under the supervision of our research team, as part of classes in an introduction to research.

8 The coding of the data was conducted by Véronique Soulé, a specialist in children's literature, as part of a research programme conducted by the CIRCEFT-ESCOL team.

9 In what follows, the term "simple text" therefore refers to the books that have been coded as such, excluding books that are both "traditional" and simple, which are coded as "traditional" for clarity. Each book is coded as only one of the three categories. 
« complexe » (par opposition à « explicite ») quand il répond clairement à l'un, au moins, des trois critères suivants, identifiés par d'autres disciplines mais dont la prise en compte a été « sociologisée » sous l'angle des activités cognitives sollicitées.

1) les textes et les images ne sont pas dans un rapport de redondance mais de complémentarité ou de discordance, apportant au lecteur un autre sens que celui de l'oralisation du texte : nombre d'études littéraires (Nières-Chevrel 2009) ou didactiques (Boiron 2006) $)^{10}$ montrent cette évolution dans les formes narratives ou les réquisits scolaires dans l'usage des albums. Nous avons repris ces constats à notre compte, mais en les sociologisant : si nous avons étudié les livres en relevant le type de relation entre textes et images, ce n'est pas pour confirmer la plus grande créativité des artistes ou la richesse des narrations, mais pour nous demander quels schèmes de perception sont sollicités. Nous avons ainsi considéré que la perception des significations suggérées n'allait pas de soi mais supposait un « code » de confrontation des indices plurisémiotiques (texte, image, texte dans l'image, typographie, etc. - Bautier, Crinon, Delarue, Marin 2012) dont il fallait vérifier quels types de familles accompagnaient ou non la construction.

2) le sens du livre change profondément si l'on identifie des allusions à d'autres œuvres (de la culture enfantine ou générale, de la littérature ou d'autres arts - Chartier 2009) ou à un genre littéraire et à ses variantes décortiquées par les études littéraires (par exemple les versions détournées du Petit Chaperon rouge

10 Les références citées ne représentent qu'une brève sélection illustrative des grandes tendances parmi les multiples que contient l'état de l'art réalisé (voir nos publications pour les détails de celui-ci). Même remarque pour les critères suivants. here based on criteria taken from an interdisciplinary review of the literature. Thus, a picture book is considered "complex" (as opposed to "simple") when it responds clearly to at least one of the three following criteria. These criteria were identified by other disciplines, but have been "sociologized" from the perspective of the cognitive activities they mobilize.

1) The text and images are not redundant but complementary or discordant, providing the reader with additional information or meaning to what is articulated in the text. Many literary (NièresChevrel 2009) or didactic (Boiron 2006) ${ }^{10}$ studies demonstrate this evolution in narrative forms or academic requirements in the use of picture books. We adopted these observations and rendered them sociological by studying books and identifying types of relationship between the text and the images, not to confirm the creativity of the artists or the richness of the narratives, but to ask which patterns of perceptions were solicited. We thus consider that the perception of these suggested meanings is not self-evident but requires a "code" confronting pluri-semiotic clues (text, image, text in the image, typography, etc. Bautier, Crinon, Delarue, Marin 2012), and that it is therefore necessary to verify which types of families accompany (or not) the construction of this code.

2) The meaning of the book changes significantly if we identify references to other texts (from children's or general culture, literature, or other arts-Chartier 2009) or to a literary genre and its variants deconstructed by literary studies (as in, for example, the various modern versions of fairy tales and, in particular, Little red

10 The references cited here represent only a small selection illustrating the major trends among the many that are present in the overview of the literature (see our publications for the details). This is also true for the following criteria. 
- Connan-Pintado 2010) : il s'agit de vérifier que ces allusions sont saisies ou non, et utilisées pour accéder à des significations tacites.

3) les formes narratives ne sont pas linéaires (fil des événements à reconstruire par exemple) et ne délivrent pas explicitement le sens principal de l'histoire notamment quand les conclusions sont ouvertes ou à formuler (Ewers 1996). Si les études littéraires et narratologiques voient là, comme dans les critères précédents, une plus grande richesse pour les enfants, ou les didacticiens des opportunités d'apprentissage pour les élèves, la transposition sociologique de ces constats conduit à se demander quels enfants sont accompagnés ou pas pour conduire ces activités cognitives implicitement requises.

Ainsi, le ciblage des activités cognitives (inférences, comparaisons, déductions, formulation d'une conclusion, etc.) prises en compte a largement reposé sur les apports d'autres disciplines, en particulier les études littéraires et narratologiques, l'histoire de la littérature, la psychologie des apprentissages et la didactique qui sont avec la sociologie des disciplines contributives des sciences de l'éducation.

La connaissance de ces apports représente un " coût d'entrée " pour le chercheur venant d'une autre discipline, ici la sociologie, devant se familiariser avec différentes bibliographies, s'informer dans diverses communautés scientifiques. Car les questions posées par ces travaux ne sont pas formulées dans les mêmes termes, ce qui ne simplifie pas le repérage des références scientifiques par mots clés. La lecture des travaux, l'acclimatation avec de nouveaux questionnements et la fréquentation de nouveaux réseaux scientifiques nécessitent du temps. De plus, il ne suffit pas de découvrir de nouvelles connaissances sur l'évolution de la littérature de jeunesse : des « frais de douane » sont liés à l'emprunt
Riding Hood-Connan-Pintado 2010). The point here is to verify whether these allusions are understood or not, and whether they are used to access tacit significations.

3) The narrative forms are non-linear (the chain of events must be reconstructed, for example) and do not explicitly reveal the primary meaning of the story, particularly when the conclusions are open or must be formulated (Ewers 1996). Although literary or narrative studies view this case (as they do for the preceding criteria) as providing greater richness for children, and pedagogues see opportunities for learning, the sociological transposition of these observations leads us to enquire as to whether or not children are accompanied in performing these implicitly demanded cognitive activities.

Thus, the targeting of cognitive activities (inference, comparison, deduction, formulation of a conclusion, and so forth) was essentially based on contributions from other disciplines. In particular, it draws on literary and narrative studies, history of literature, psychology of learning, and didactics, which are-along with sociology-the key disciplines contributing to education sciences.

Knowledge of these contributions constitutes an "entry cost" for researchers coming from other disciplines, in this case sociology, who must familiarize themselves with different bibliographies and become informed about new scientific communities. Because the questions raised in these studies are not formulated in the same terms, it is not always easy to identify the scientific references by keywords. Reading the studies, adjusting to new questioning, and becoming familiar with new scientific networks all requires time. Moreover, it is not sufficient to discover new materials on the evolution of children's literature; there are "importation costs" linked to borrowing knowledge from one discipline to use in another. 
de connaissances à une discipline pour les utiliser dans une autre. En effet, cet emprunt implique un travail de reconfiguration, et pas seulement de reprise, pour que l'objectivation d'évolutions narratologiques puisse être envisagée comme une évolution des pré-requis à la compréhension de l'histoire.

Mais les « coûts » liés à ces emprunts peuvent aussi aller de pair avec des « coups » dont il faut se protéger. Nous en avons un peu fait l'expérience en apportant un regard sociologique sur l'album de jeunesse et ses usages dans des réseaux scientifiques qui avaient jusqu'ici la quasi exclusivité sur l'objet : le regard sociologique met à distance la « richesse » des œuvres que ces chercheurs ont préalablement mise en évidence, non pas pour dénier ce constat, mais pour interroger les conditions de connaissances et d'habitudes à mobiliser des activités cognitives pour que cette richesse soit accessible. De fait, on pointe alors un point aveugle des recherches précédentes, quand les lecteurs effectifs diffèrent des « lecteurs supposés " qu'elles ont mis au jour. Or, ces recherches inspirent souvent des pratiques de formation visant à encourager enseignants ou bibliothécaires à utiliser plutôt des albums « implicites » qui, selon la formule fréquente de pédagogues, « font appel à l'intelligence de l'enfant ». II nous est alors arrivé d'être suspecté par ces collègues de contribuer à " désenchanter la culture ", à décourager l'utilisation de ces ouvrages au profit de livres de "bas niveau ", les préoccupations axiologiques, quant aux implications sociales de la recherche, prenant la forme de résistances à l'objectivation sociologique.

Mais l'usage sociologique de ces connaissances constitue aussi un « bénéfice transfrontalier » pour le « passeur ». C'est d'abord un gain de temps pour identifier des critères pertinents dans l'évolution des albums, car une fois payé le coût d'entrée dans de nouveaux domaines bibliographiques, le jeu des références
Indeed, these borrowings imply reconfiguration as well as reuse, in order for the objectivity of the narrative evolutions to be considered as an evolution of the prerequisites to the understanding of the story.

But the "costs" associated with this importation may also involve "setbacks" which must be protected against. We experienced this to some extent in providing a sociological perspective on children's books and their uses, being met with a certain degree of mistrust in scientific networks (particularly in literary studies), which up until recently had a near monopoly on the object. The sociological perspective distances itself from the "richness" of the texts, previously demonstrated by these researchers, not to deny that observation but rather to question the conditions of knowledge and habits that condition the cognitive activities which make this richness accessible. Indeed, we identified a blind spot in previous studies, when the actual readers differ from the "supposed readers" that these studies brought to light. Yet these studies often inspire training practices that aim to encourage teachers or librarians to use "implicit" picture books that "draw on the intelligence of the child" according to the expression frequently used by pedagogues. Certain colleagues even suspected us of contributing to the "disenchantment of culture"-of discouraging the use of these books in favour of "lower quality" ones. These were axiological concerns regarding the social implications of this research, taking the form of resistance to sociological treatment.

But the sociological use of this knowledge also provides a "crossborder benefit" for whomsoever is the "vector" of this importation. Firstly, it saves time in identifying the criteria relevant to the evolution of picture books, because once the entry costs have been paid for new bibliographic fields, the interplay of scientific references 
scientifiques facilite le repérage de ces différents critères distingués par les disciplines visitées. II s'agit aussi d'un gain symbolique et académique dans d'autres disciplines par l'effet de l'intérêt qui leur est accordé, ouvrant des possibilités de communication, publication

et projets partenariaux plus nombreux.

Le bénéfice existe aussi dans les réseaux sociologiques, par l'apport d'aspects méconnus et pourtant utiles. Mais là aussi, cela occasionne certains coûts, d'explicitation du bien-fondé de ces emprunts hétéroclites, comme de la centration sur les activités cognitives, quand la discipline a longtemps délaissé cet objet, comme plus généralement l'activité des enfants, aux psychologues ou aux didacticiens (Passeron 1991 ; Isambert-Jamati 2005). L'intérêt pour les instruments de socialisation et les activités cognitives des enfants constituent un enjeu de connaissance sociologique, et pas seulement de «préoccupations pédagogiques » comme on peut parfois l'entendre.

L'analyse des bibliothèques domestiques montre que le type d'albums fréquentés de manière préférentielle exerce inégalement les enfants à mobiliser telle ou telle activité socio-cognitive : retenir et identifier des sens « explicites »; retenir des récits patrimoniaux et intérioriser des trames standards dans les contes ; décoder les implicites, les allusions et sens cachés ${ }^{11}$. Un deuxième critère de codage a été appliqué pour cette recherche : ces albums appartiennent-ils à la sphère légitime de la production littéraire enfantine (auteur ou éditeur qui se sont vus décerner un prix ou ont bénéficié de recensions dans les revues professionnelles de référence)?

11 À la différence des «théories de la réception » qui n'ont pas étudié les réceptions effectives (Mauger 1999), le « lecteur supposé » objectivable dans le livre est ici confronté aux pratiques des lecteurs effectifs. facilitates the identification of the different criteria distinguished in the disciplines visited. It also represents a symbolic and academic advantage for other disciplines due to the interest that is accorded to them, opening up possibilities for increased communication, publication, and partnership projects.

There is also a benefit for sociological networks, in the contribution of useful but less well-known aspects of the subject. However, once again, this produces certain costs, including the need to justify the legitimacy of these heteroclite references, and indeed the focus on cognitive activities, when sociology as a discipline has long abandoned this object, along with the activity of children more generally, to psychologists and pedagogues (Passeron 1991; Isambert-Jamati 2005). The instruments of socialization and the cognitive activities of children are indeed issues for sociological investigation - rather than only being "pedagogical concerns" as is sometimes claimed.

The analysis of home libraries demonstrates that preferences for different types of picture book make uneven demands on children to mobilize particular socio-cognitive activities: remember and identify "explicit" meanings; remember traditional stories and internalize standard narrative threads in fairy tales; and decode what is implicit, alluded to, or double meanings ${ }^{11}$. A second coding criterium was applied in this research: do these books belong to the legitimate sphere of literary production for children (has the author or editor been awarded prizes or been reviewed in key professional journals)?

11 Unlike "theories of reception," which have not studied actual reception (Mauger 1999), the "supposed reader," as objectified by the book, is confronted here with the practices of actual readers. 
Nous présentons d'abord les résultats de cette enquête sur l'exposition plus ou moins fréquente des enfants, selon les caractéristiques de leurs familles, aux différents types d'albums. L'analyse multivariée étant encore en cours, nous montrerons les très nets écarts observables selon les caractéristiques sociales des familles, avant de nous consacrer aux apports de l'interdisciplinarité dans une enquête de ce genre.

\subsection{Pratiques légitimes et éclectiques, résultats d'une} socialisation

Même si cette recherche n'a pris en compte que les familles possédant des livres, beaucoup de familles populaires sont présentes dans le corpus. Contrairement aux idées répandues chez les enseignants et les professionnels de la culture, on trouve en effet assez fréquemment des livres de jeunesse dans les familles les plus économiquement démunies et les moins diplômées. Les inégalités entre types sociaux d'enfants en matière de lecture avant l'autonomie lectorale ne tiennent donc plus principalement à la présence ou à l'absence du livre au foyer, et donc à la familiarité avec cet objet, situation qui prévalait probablement il y a une cinquantaine d'années. Ces inégalités se sont déplacées.

D'abord, le nombre de livres à disposition reste inégal : il croît au fur et à mesure que l'on s'éloigne des classes populaires. De deux ou trois livres pour des enfants qui sont les benjamins de la fratrie dans les familles les plus démunies, à plus d'une cinquantaine pour la plupart des enfants de cadres, et parfois bien au-delà, jusqu'à 300 pour l'aîné d'une fratrie de deux. À niveau socio-économique équivalent, le profil « éducatif » ou «culturel », dans les formations ou les métiers des parents, va de pair avec un volume d'albums supérieur. Ainsi, dans les catégories diplômées, les enfants d'enseignants, d'artistes ou de cadres de la culture
We will begin by presenting the results of this study of the frequency of exposure of children to different kinds of picture book, depending on the characteristics of their family. As the multivariate analysis is still under way, we will demonstrate the very clear differences that can be observed depending on the social characteristics of families, before focusing on the contributions interdisciplinarity can make to this kind of study.

\subsection{Legitimate and Eclectic Practices: The Results of Different Socializations}

Although this research only included families who own books, there is a high proportion of working-class families in the corpus. Contrary to ideas that are widespread among teachers and those working in the culture industry, we frequently find children's books in the most economically disadvantaged and the least educated homes. The inequalities that exist between the social backgrounds of children in terms of reading, before independent reading is reached, are therefore not primarily due to the presence or absence of books in the household, nor with the familiarity with this object, which may have been the case fifty years ago. These inequalities have shifted.

Firstly, the number of books available remains extremely unequal and increases steadily as we move away from the working classes. It ranges from two or three books each for the youngest children in the most disadvantaged families, to more than 50 for most upper middle-class children, and sometimes many more than that-up to 300 for the eldest of two siblings in one instance. For a given socioeconomic level, the "educational" or "cultural" profiles of the parents' qualifications and professions is associated with an increased volume of children's books. Therefore, among the more highly educated (children of teachers, artists, cultural professionals, etc.), 
ont des bibliothèques souvent plus fournies que ceux de cadres commerciaux ou techniques. De même, dans les catégories populaires, les assistantes maternelles, ou les animateurs de centres de loisirs, notamment du fait de formations qu'ils ont suivies ou de leur intérêt professionnel pour la culture enfantine, achètent ou empruntent tendanciellement plus d'albums pour leurs propres enfants que les parents du même niveau de revenus, ouvriers ou employés.

Le déplacement des inégalités réside encore dans le contenu de ce que les enfants sont amenés à fréquenter. Les enfants des classes populaires fréquentent essentiellement des albums « explicites », produits par des éditeurs du pôle de la grande production : souvent fondés sur un héros médiatique (TV, cinéma) ou une série. Dans ces albums, le texte délivre ce qui est à comprendre, la structure narrative est répétitive ou sans surprise. II s'agit de la conséquence de choix sur d'autres critères. Les parents disent ainsi laisser le plus souvent l'enfant choisir ce qu'il préfère (qui est ce qu'il a repéré à la télévision ou qui est à la mode chez les copains). Le seul véto qu'ils mettent est moral, le livre ne devant pas être « choquant » (thèmes, langage grossier, etc.). Quand les parents des classes populaires choisissent les albums, ils mettent en œuvre les mêmes critères de garantie en privilégiant ce qui semble « reconnu » comme faisant partie de la culture enfantine : les adaptations de dessins animés notamment. À l'inverse, les albums « patrimoniaux » sont rares dans ces familles. Et la présence, exceptionnelle, d'un album " complexe " s'explique par l'action d'une institution (abonnement recommandé par un enseignant, livre connu par l'enfant dans une institution et réclamé).

Cela confirme le constat d'« univorité » des classes populaires dans les répertoires les moins légitimes, tout en le complétant : c'est dès l'enfance que les classes populaires fréquentent une moindre children often have libraries that are better stocked than those in the families of commercial or technical managers. Similarly, among working class, childcare or holiday centre workers tend to buy or borrow more books for their own children than the parents of the same level of income who are workers or employees, largely due to the training they have received or their professional interest in children's culture.

The shift in inequalities also lies in the content of the books that the children are likely to encounter. Children from working-class families essentially have access to "simple" picture books, often mass produced by publishers, merchandizing spin-offs from television series or the cinema based on a hero or character. In these books, the text provides what needs to be understood and the narrative structure is repetitive or unsurprising. This is the result of choice based on other criteria. Parents thus say they let the child choose what they prefer (what they have seen on television or what is fashionable among their peers). The only veto they enforce is a moral one-the book must not be "shocking" (themes, vulgar language, etc.). When working-class parents choose books, they use the same criteria, preferring what seems to be "recognized" as being a part of children's culture, and particularly adaptations of cartoons. Conversely, "traditional" books are rare in these families, and the (highly unusual) presence of a "complex" book can be explained by the influence of an institution (a subscription recommended by a teacher, a book encountered by the child in an institution and requested).

This confirms the observation of the working classes' "univorous" cultural consumption of less legitimate repertoires, and furthermore suggests that this limited diversity begins in childhood. Our 
diversité de produits culturels. Notre recherche montre surtout que lorsque les critères de choix des albums sont modelés par les canaux les moins légitimes, les enfants se retrouvent confrontés principalement à un même type d'albums « explicites », favorisant l'intériorisation de trames standards de récits et de certaines activités cognitives (comme la mémorisation de la morale délivrée par le livre), ce qui est utile dans une phase de construction de dispositions lectorales, mais n'aide pas à appréhender des types de récits plus variés.

À l'opposé, les enfants d'enseignants ou de professionnels de la culture ont une bibliothèque « éclectique » : ils possèdent aussi des albums « explicites », mais en proportion limitée. Une première explication tient au fait que les parents rejettent souvent les produits les plus ouvertement commerciaux (séries fondées sur un héros et fabriquées, selon eux, « à la chaîne », produits dérivés de dessins animés, etc.). Ensuite, dans leurs bibliothèques domestiques, on trouve beaucoup d'albums « patrimoniaux » et « complexes », ces derniers étant diffusés par des éditeurs légitimes.

La diversité des ouvrages mis à disposition des enfants dans ces milieux découle de la pluralité des modalités de choix des albums, entre une part de décision laissée à l'enfant pour faire comme les copains, et une part de choix des parents, désireux de faire découvrir des auteurs, des collections, etc., ou de se laisser conseiller par des médiathécaires et libraires spécialisés. La conséquence est que ces enfants sont bien plus fréquemment en possession d'ouvrages qui transmettent les codes culturels des récits " patrimoniaux ", auxquels les albums " complexes" font allusion en les détournant, et qu'ils sont confrontés, avec ces ouvrages complexes, à des sollicitations à décoder les implicites et les jeux narratifs tacites. research demonstrates above all that when the criteria for the choice of picture books are shaped by less legitimate channels, children are primarily exposed to the same kind of "simple" books that encourage the internalization of standard narrative threads and certain types of cognitive activities (such as memorizing the moral of the story). This is useful in constructing dispositions for reading, but does not help children to negotiate a range of different types of story.

At the opposite end of the spectrum, children of teachers or cultural professionals have "eclectic" libraries. They possess some "simple" books, but the proportion is more limited. An initial explanation of this lies in the fact that their parents often reject more overtly commercial products. In addition, their home libraries also include many "traditional" and "complex" books, the latter being distributed by legitimate publishing houses.

The diversity of works available to children in these environments stems from the plurality of modalities in the choice of picture books, with part of the decision delegated to the child-to conform to the peer group-and part of the decision made by parents, who seek to expose their children to particular authors, collections, and so forth, or who are advised by librarians and specialist booksellers. The consequence is that these children are more frequently in possession of books that transmit the cultural codes of "traditional" narratives, which the "complex" books allude to and divert. As a result, children are invited to decode tacit wordplay and implicit elements in the narratives of these complex books. 
Entre les deux pôles de ces types de familles, il existe tout un dégradé. On peut rapidement mettre au jour des parents des classes populaires titulaires d'un $\mathrm{BEP}^{12}$ ou d'un baccalauréat professionnel, et qui, plus souvent que les catégories populaires déjà évoquées, mettent à disposition de leurs enfants des albums " patrimoniaux » car ils estiment importante la transmission de la culture traditionnelle, par exemple des contes, associés à la culture enfantine. On trouve aussi des enfants de cadres techniques ou commerciaux dont les bibliothèques contiennent des albums " implicites », mais dans une proportion moindre que celles des enfants d'enseignants.

Ces résultats tendent en partie à confirmer la théorie de l'omnivorité (Peterson 2004 ; Donnat 1994), tout en la relativisant comme étant une forme actualisée de la légitimité culturelle (Coulangeon 2004 ; Fabiani 2013). Ils montrent aussi, pour la lecture, que la socialisation aux «préférences » se fait dès l'enfance. Les classes populaires socialisent leurs enfants à la fréquentation d'œuvres " grand public » et explicites, et très peu à la fréquentation d'œuvres légitimes et complexes, tandis que les familles en connivence avec les attendus éducatifs et artistiques habituent très tôt à lire des livres issus de domaines de la production inégalement légitimes.

Simultanément, ces résultats interrogent ces théories de l'omnivorité.
Between these two extremes there is a sliding scale of family situations. We are able to rapidly identify working-class parents with vocational education who provide their children with "traditional" books more often than the working-class categories already mentioned because they consider the transmission of traditional culture - through fairy tales, for example - to be important. We also observe children of technical and commercial managers whose libraries contain "implicit" or complex books, but to a lesser extent than those of the children of teachers.

The results partly tend towards a confirmation of the theory of omnivorous cultural consumption (Peterson 2004; Donnat 1994), while also relativizing it as a contemporary form of cultural legitimacy (Coulangeon 2004; Fabiani 2013). We also demonstrate that as far as reading is concerned, socialization to "preferences" occurs from early childhood. The working classes socialize their children to simple, "commercial" children's books and give them little exposure to more legitimate and complex works. Children from families who conform to educational and artistic expectations, on the other hand, adapt to reading books from different spheres of production and of different degrees of legitimacy when they are still very young.

However, these results also challenge theories of cultural omnivorousness.

12 Brevet d'études professionnelles : diplôme d'études secondaires et diplôme d'enseignement professionnel. 


\subsection{Au-delà de la légitimité et de l'éclectisme, les activités} socio-cognitives d'appropriation

Le premier point de débat porte sur la manière d'étudier la diversité des pratiques, ici lectorales. En effet, le modèle de l'omnivorité et ses variantes ou celui de la tablature des goûts piochés de manière variable dans des répertoires divers (Glevarec \& Pinet 2009), traitent, selon leur niveau d'analyse, les genres (littéraires, musicaux ou autres) ou les œuvres (les livres, les chansons, etc.), comme des éléments dont le chercheur mesure statistiquement les présences corrélées ou non chez les mêmes individus, et leur affecte un indicateur de légitimité.

Ces remises en cause de la théorie de la distinction se fondent principalement sur l'un des volets de celle-ci, selon lequel les catégories en position dominante dans le champ culturel tendent à faire reconnaître de façon " arbitraire » leurs propres répertoires comme plus légitimes que les autres. Elles ont ainsi constaté, après Bourdieu, que les types de répertoires préférés par chaque catégorie sociale ne relèvent pas uniquement de la sphère de la légitimité pour les uns, et de l'illégitimité ou du goût « populaire » pour les autres. II a également été montré que certains répertoires avaient plus largement été diffusés et avaient changé de consommateurs. Ce faisant, ces remises en cause de La Distinction ont principalement axé leur argumentation sur le fait que les critères de légitimité étaient affaiblis, ainsi que, par conséquent, le pouvoir d'imposition d'une table des valeurs par les catégories dominantes.

Mais comme nous l'avons évoqué dans la première partie, ces critiques de la théorie de « la distinction » ont pour la plupart laissé de côté un pan de la question : elles n'interrogent pas les formes de perception et les activités cognitives engagées dans l'appréhension

\subsection{Beyond Legitimacy and Eclecticism: Socio-Cognitive Activities in Appropriation}

The first point of debate concerns the way in which diversity of practices - in this case reading practices-may be studied. Indeed, the omnivore model and its variations tastes adopted in various ways from different repertoires and combined to form "tablatures" (Glevarec \& Pinet 2009) consider, depending on their level of analysis, genres (literary, musical, or other) or works (books, songs, etc.) as elements that the researcher measures as being correlated (or not) in the same individuals and associates with an indicator of legitimacy.

These challenges to the theory of distinction are primarily based on one of the aspects of this theory, according to which the categories that are dominant in the cultural space tend to recognize their own repertoires "arbitrarily" as more legitimate than others. These critiques have therefore observed, after Bourdieu, that the types of repertoire preferred in each social category do not merely stem from the legitimate sphere for some and the illegitimate sphere or "popular tastes" for others. It has also been demonstrated that certain repertoires have been more broadly distributed, and that their consumers have changed. Thus, these challenges to Distinction mainly focus on the argument that the criteria of legitimacy have been weakened, and as a result, so too has the power of dominant categories to impose a set of values.

However, as mentioned in the first section, these critiques of the theory of distinction have for the most part neglected one aspect of the question: they do not investigate the forms of perception and the cognitive activities involved in understanding repertoires of 
des répertoires d'œuvres. Elles se bornent à constater de manière binaire les types d'œuvres ou genres consommés ou pas. Or, dans la théorie de Bourdieu, la question de la légitimité est articulée à des schèmes de raisonnement précis : ce ne sont pas seulement les œuvres qui sont « savantes » et donc légitimes, c'est la manière de les apprécier, la capacité à en parler, à les situer dans des époques, des courants, et à les comparer sur des critères formels.

Si les classes dominantes dans le champ culturel tirent un profit distinctif des différences de répertoire et des différences de formes de perception, simultanément, elles tirent un autre profit, direct et non comparativement aux autres catégories : c'est la possibilité, dont sont privées les classes les moins instruites, de " décoder ", d'apprécier et de mettre en relation les œuvres « savantes ». Le raisonnement de Bourdieu articule une théorie de l'espace social (et donc des distinctions et de la promotion arbitraire de certaines valeurs au détriment d'autres) et une théorie de la pratique pour étudier l'appréhension du monde par les êtres sociaux, laquelle ne se réduit pas à une lutte de places sur des critères arbitraires : les possibilités de décoder ou non un album, par exemple quand la narration joue sciemment à masquer des sens pluriels, donnent aussi du pouvoir sur les choses manipulées et sur soi-même (permettant de développer de nouvelles formes de compréhension, de nouveaux goûts), et pas seulement du pouvoir sur les autres êtres sociaux (ici dans la hiérarchie des lecteurs, capables de comprendre ou non).

Si les œuvres moins légitimes sont consommées aussi par les classes dominantes, cela ne suffit pas à dire que ce qui caractérise l'omnivorité, ce serait la diversité des répertoires pratiqués. Car pour être distinctif, et non disqualifié, cet éclectisme doit être non pas « tous azimuts » mais « éclairé » (Coulangeon 2004 : 68). Il apparaît alors nécessaire de s'intéresser de plus près aux différentes formes artistic or literary works. They limit themselves to observing-in a binary manner-the types of works or genres that are consumed or not. Yet in Bourdieu's theory, the question of legitimacy is linked to particular schemata of reasoning: it is not only the works themselves that are "scholarly" and therefore legitimate; it is also the ways of approaching them, the ability to discuss them, to situate them within eras and movements, and to compare them using formal criteria.

Although the dominant classes within a cultural field draw distinct profit from these differences in repertoire and in forms of perception, they also simultaneously benefit in another way, directly rather than in comparison with other categories. They benefit from the ability to "decode" appreciate, and make connections between "scholarly" works, which is something that less educated classes are deprived of. Bourdieu's reasoning articulates a theory of the social space (and thus the arbitrary distinction and promotion of certain values to the detriment of others) with a theory of practice, to study the perception of the world by social beings, which cannot be reduced to a struggle for places according to arbitrary criteria. The possibilities of decoding a picture book or not-for example when the narrative intentionally plays on implicit double meanings-confers power onto the things thus manipulated and onto oneself (enabling the development of new forms of understanding, new tastes), and not only power over other social beings (here in the hierarchy of readers, those able to understand or not).

While less legitimate works are also consumed by dominant classes, this is not sufficient to say that what characterizes omnivorousness is the diversity of repertoires mobilized. Because in order to be distinctive, rather than disqualified, this eclecticism must not be "random" but rather "enlightened" (Coulangeon 2004: 68). It therefore appears necessary to focus more closely on different 
d'appréciation des mêmes œuvres, et notamment aux emprunts aux répertoires plus populaires ou marchands qui font l'objet d'une appropriation « savante ». C'est ce qui était déjà pointé au sujet des étudiants " héritiers » : ils transposent les schèmes de perception littéraires sur des pratiques culturelles libres moins légitimes, par exemple dans leurs commentaires savants sur les œuvres de jazz et de cinéma, ce qui est qualifié d'« éclectisme averti » (Bourdieu

\& Passeron $1964: 30$ )

Si les pratiques culturelles sont de plus en plus des occasions de sociabilité (Pasquier 2005), c'est qu'elles font l'objet d'un partage, soit par une pratique "par corps ", soit par un échange, avec une mise en discours qui confronte les répertoires pratiqués. Ce qui est distinctif dans l'éclectisme pourrait donc ne pas résider seulement dans la capacité à avoir des goûts pluriels, mais dans la possibilité de mettre en cohérence relative les pratiques et répertoires " dissonants " (Lahire 2004) et de relier des éléments éloignés à partir de critères savants. Ce qui permet de se distinguer, en apportant des points de vue plus réflexifs, des regards ou lectures " ordinaires ", qui se contentent des significations « explicites" de l'œuvre. Inversement, l'omnivore éclairé ne peut être celui qui se caractérise par la seule appropriation du sens premier (significations explicites) et "par corps » ou « participative " (suspens, identification - Renard 2011) de répertoires légitimes : ceux-ci sollicitent des dispositions "scolastiques " nécessaires pour s'approprier leur diversité de sens cachés ou d'allusions. Par conséquent, les recherches doivent aussi porter sur les modalités du lire et de la socialisation à celles-ci lors des lectures partagées.

Nous transposons ici en sociologie de la culture les approches développées en sociologie de l'éducation sur les activités cognitives inégalement mobilisées par les élèves. forms of appreciation of the same works, and particularly on the "scholarly" appropriations of more working-class or commercial repertoires. This has already been discussed in relation to the students from more privileged backgrounds documented in The Inheritors, who transpose the patterns of literary perception onto less legitimate cultural practices consumed in their free time, for example in their scholarly comments on works of jazz or cinema, which is described as "shrewd eclecticism" (Bourdieu \& Passeron 1979: 17)

If cultural practices are more and more opportunities for sociability (Pasquier 2005), this is because they are shared, either through bodily practice or through an exchange via a discourse that confronts the repertoires mobilized. What is distinctive about this eclecticism may not lie only in the ability to have diverse tastes, but also in the possibility of making "dissonant" practices and repertoires relatively coherent (Lahire 2004) and connecting remote elements based on scholarly criteria. This enables them to be distinguished from "ordinary" gazes or readings that limit themselves to "simple" or explicit significations in the text, by contributing perspectives that are more reflexive. However, an enlightened omnivore cannot be characterized simply by their appropriation of the initial meaning (explicit significations) and "bodily" or "participative" (suspense, identification-Renard 2011) appropriations of legitimate repertoires. The latter draws on the "scholarly" dispositions required for appropriating the range of hidden meanings and allusions. As a result, research must also cover the modalities of reading and how children are socialized to these during shared reading sessions.

Here we transpose the approaches developed in the sociology of education regarding the cognitive activities that are unevenly mobilized by students, onto the sociology of culture. 


\subsection{Les activités socio-cognitives lors des lectures partagées dans les familles}

Pour accéder aux modalités du lire, un deuxième corpus a été constitué par recueil, dans une diversité sociale de familles, de séances filmées de lectures partagées de deux albums, séances suivies à chaque fois d'un entretien d'explicitation des pratiques observées $\left(\mathrm{N}=87^{13}\right)$. Les albums, fournis par l'enquêteur ${ }^{14}$, étaient pour l'un « patrimonial » (La Chèvre et les biquets, version du Père Castor, 1958) et pour l'autre « complexe » (avec un loup rencontrant des personnages de contes traditionnels qui ont déjà eu affaire à lui : Le Petit Chaperon rouge, Les Trois Petits Cochons, etc.). Le choix de deux livres comportant un personnage de « loup » visait à voir ce que le parent et l'enfant faisaient, ou non, de la confrontation possible entre les deux albums : la lecture partagée habitue-t-elle à appréhender une histoire en la comparant à d'autres (personnages communs, ressorts narratifs similaires, versions différentes, etc.) et en la situant par rapport aux codes d'un genre littéraire, ici le conte traditionnel, dont la trame est respectée par un album et détournée par l'autre ? La lecture conjointe attire-t-elle l'attention vers des ouvrages des mêmes auteurs et de la même collection, etc. ? Habitue-t-elle à suspecter le narrateur textuel d'attirer le lecteur vers de fausses pistes pour mieux lui laisser le plaisir de décoder les sens cachés grâce à des indices discrets glissés dans l'image ou les sous-entendus du texte?

13 Ici encore, après des observations et entretiens recueillis par nos soins dans dix familles, les autres l'ont été par des étudiants encadrés dans des cours d'initiation à la recherche dans le département des Sciences de l'éducation de Paris 8.

14 Les aspects théorico-méthodologiques relatifs aux conditions bien spécifiques dans lesquelles nous défendons l'usage de techniques " expérimentales à des fins sociologiques, ne sont pas développés ici, il fait l'objet d'une contribution à paraître.

\subsection{Socio-Cognitive Activities Mobilized in Shared Reading in Families}

In order to access the modalities of reading, a second corpus was constructed by producing video recordings of shared (adult-child) reading sessions of two picture books in families from a range of social backgrounds, the sessions being systematically followed by an interview explaining the practices observed $\left(\mathrm{N}=87^{12}\right)$. The picture books were provided by the interviewer ${ }^{13}$ and included a "traditional" text (La Chèvre et les biquets, a version of the traditional story The Wolf and the Seven Kids published by Père Castor in 1958) and a "complex" text (in which a wolf meets the various characters from fairy tales who have already encountered himLittle Red Riding Hood, the Three Little Pigs, etc.). The choice of these two books, both including the character of the "wolf," aimed to find out what the parent and the child made (or not) of the possible comparison between them. Does shared reading help children get used to understanding a story by comparing it to others (shared characters, similar narrative foundations, different versions, etc.) and by situating it within the codes of a literary genre, here fairy tales, which is respected by one book and distorted by the other? Does shared reading draw attention to works by the same author, or in the same collection, and so forth? Does it help the reader to become accustomed to anticipating the introduction of red herrings or false clues by the narrator in order to give the reader the added pleasure of decoding hidden meanings through discrete clues slipped into a picture or implied in the text?

12 Once again, after observation and interviews collected in ten families, the remaining interviews were conducted by students supervised as part of a class on initiation into research methods at the Department of Education Sciences at University Paris 8.

13 The theoretical and methodological aspects relating to the very specific conditions in which we promote the use of "experimental" techniques in sociology is not developed here. It is the subject of a forthcoming publication. 
Nos résultats montrent que la socialisation au lire qui s'effectue à cette occasion varie selon les caractéristiques sociales et culturelles des familles, y compris au sein des classes populaires : si elles ont des points communs, les familles de cette catégorie ne sont pas uniformes.

Un premier type de familles populaires correspond aux parents qui ont bénéficié au mieux d'une scolarité primaire focalisée sur l'alphabétisation dans un pays en voie de développement (type 1). Ils lisent très peu (livre religieux, journal régional). Leurs lectures partagées, axées sur l'oralisation correcte du texte, ne prennent quasiment pas d'indices dans l'imprimé pour expliciter des non-dits ou des sous-entendus du récit ; et ces familles échangent très peu sur le contenu et les formes de l'histoire. Le livre est ici donné à voir à l'enfant comme délivrant seul sa signification et n'appelant pas de commentaire, sauf la traduction ponctuelle d'un mot jugé inconnu, ou la répétition quasiment à l'identique de la conclusion explicite de l'ouvrage. Cette manière de lire est à l'œuvre aussi bien avec l'album « patrimonial » qu'avec l'album « complexe »: elle permet d'accéder au sens premier, mais laisse opaques les significations plus implicites. Aussi, ces familles disent-elles apprécier peu l'ouvrage « complexe », ne pas en voir l'intérêt pour leur enfant, et ne pas désirer se le procurer si l'occasion leur en était offerte, mais elles ne peuvent expliquer les raisons pour lesquelles il ne leur plaît pas. Les parents demandent le plus souvent à l'enfant, après la lecture des deux albums, s'il a eu peur, associant de fait le personnage du loup à une réaction attendue, mais la présence de ce personnage dans chaque histoire n'appelle pas de commentaires particuliers ou de comparaison des deux loups, ni d'explicitation du comportement typique de cet animal dans les contes. Ces parents ne connaissent ni La Chèvre et les biquets (album patrimonial) ni les autres récits traditionnels auxquels fait allusion l'album « complexe » sauf Le Petit Chaperon rouge et Les
Our results show that the socialization to reading that happens on these occasions varies according to the social and cultural characteristics of the families, including within the working classes: although there are commonalities, the families in this category are by no means uniform.

The first type of working-class family includes parents who at best received basic schooling and literacy in a developing country (Type I). They read very little, primarily religious texts and local newspapers. Their shared reading is focused on the correct articulation of the text and almost never take into account the textual clues to explain the implications or double meanings of the narrative; and these families discuss the content and form of the story very little. The book is presented to the child as though it alone provided its meaning and required no commentary except for the sporadic translation of a word considered unfamiliar, or the near identical repetition of the explicit conclusion in the book. This way of reading applies to both the "traditional" and the "complex" book: it allows children to access the primary meaning of the text, but leaves them in the dark as to the more implicit meanings. These families therefore say they do not like the "complex" text and do not see what their child could gain from reading it; they say they would not choose to buy it if they had the opportunity to do so, but also that they cannot explain why they do not like it. After reading the two books, the parents most often asked the child if they were afraid, associating the presence of the wolf with an expected reaction, but the presence of this character in both stories does not provoke particular commentaries or comparisons between the two wolves, nor an explanation of the typical behaviour of this animal in fairy tales. These parents are not familiar with the traditional story of The Wolf and the Seven Kids, nor of the other fairy tales that are referred to in the "complex" book (with the exception of Little Red Riding Hood and The Three Little Pigs). However, these two well- 
Trois Petits Cochons ; mais ces deux histoires connues n'appellent aucun commentaire et ne donnent aucune clé de lecture de la nouvelle histoire.

Un second cas de familles populaires (type 2) se distingue, avec des parents scolarisés en France jusqu'au collège ou en cycle court (CAP, BEP voire bac pro), exerçant des emplois d'exécution, ayant peu de pratiques lectorales mais vigilants à ce que leurs enfants lisent régulièrement. Leur propre scolarité les conduit à privilégier le "sens » de ce qui doit être retenu, à savoir la moralité ou la réflexion sur l'expérience personnelle de l'enfant que l'histoire lue délivre explicitement : suivre les conseils des adultes, etc. Souvent, ces parents ne se limitent pas à répéter la conclusion mais reformulent ce qui doit être « retenu » par l'enfant et l'invitent à le répéter, à l'instar de ce que pouvait faire l'école primaire d'autrefois. Ils insistent également sur ce que le livre désigne comme des étapes narratives, par leur enchaînement logique, ou les liens de causalité entre des événements, etc. Ils sont particulièrement à leur aise avec les albums « patrimoniaux 》 dont les conclusions, voire les morales, sont explicites, et qui ressaisissent assez explicitement les liens entre les éléments qui composent l'histoire (par exemple, la mère chèvre avait donné des consignes, les biquets les ont respectées, ce qui leur a permis d'échapper au loup, elle les félicite et les récompense). Ces parents conduisent une lecture partagée similaire des albums " complexes », en insistant sur ce qu'ils ont compris : à l'inverse du premier type de famille, ils exposent très clairement les raisons de leur dépréciation des livres " sans morale », « pas clairs, flous, on ne sait pas comment ça finit ». Ils perçoivent que quelque chose n'est pas dit, mais n'imaginent pas que le sens est à découvrir. Ils connaissent un certain nombre d'histoires traditionnelles auxquelles le livre «complexe » fait allusion, et sont souvent surpris, voire gênés, que la présence du Petit Chaperon rouge, ou de l'agneau de la fable de La Fontaine, known tales do not provoke any commentary or provide any tools for interpreting the new story.

A second type of working-class family (Type II) is characterized by parents who were educated in France up until secondary school, or in vocational education, working in unskilled or lowlevel jobs, who do not read much themselves but ensure that their children read regularly. Their own schooling led them to focus on the "meaning" to be retained from texts, the moral, or an explicit reflection on the personal experience of the child that the book provides - the importance of listening to adults, and so forth. Often these parents do not limit themselves to simply repeating the conclusion of the book, but reformulate it in terms of what the child should "retain" and encourage him or her to repeat it, much as would have formerly been done in primary schools. They also emphasize the book's presentation of narrative stages, their logical connections, the causality between events, and so forth. They are particularly comfortable with "traditional" books, whose conclusions or messages are straightforward and capture the connections between the elements that make up the story fairly explicitly (for example, the mother goat giving instructions, the kids respecting them, which enables them to escape from the wolf, and she congratulates and rewards them). These parents conduct a similar reading of the "complex" picture books, focusing on what they understand-unlike the first type of family, they clearly present the reasons for their dislike for these kinds of books, claiming they "have no message," that they are "unclear, vague," or saying "you don't know how it ends." They can see that something has been left unsaid but cannot imagine that the meaning must be sought out by the reader. They are familiar with a certain number of traditional stories that the "complex" book refers to, and are often surprised, or even disturbed, by the fact that Little Red Riding Hood, or the lamb 
n'aille pas de pair avec le récit de la « vraie histoire ». Ils craignent que les enfants ne retiennent une « mauvaise version ", "fausse », et que "ça les embrouille ». De même, le comportement du loup, déviant par rapport à l'archétype dans l'album « complexe », leur fait souvent craindre que l'enfant ne soit « perdu » quand on change ses repères : ils ne prennent pas ce livre comme un jeu qui permet de situer les caractéristiques typiques du personnage en comparant le loup déviant et l'archétype.

Ils utilisent les indices dans les images quand ceux-ci sont soulignés par le texte (la farine qui tombe de la patte du loup), mais ne le font pas quand cette relation entre texte et image est tacite. La brièveté des textes est vue par eux comme un critère de moindre exigence et non comme le signe de ce que des non-dits sont à chercher : les opportunités que recèlent les albums " complexes " ne sont pas utilisées. Et même les significations explicites sont circonscrites par l'adulte, de peur que les enfants ne comprennent pas les ouvrages (« explicites » et a fortiori « complexes ») : celui-ci « referme » le sens en « corrigeant » ou complétant la lecture par la formulation du sens auquel il a accès et en excluant d'autres possibilités. La première lecture est censée "épuiser » les significations de l'ouvrage. Ces parents encouragent chez leurs enfants les activités cognitives de repérage et de mémorisation des éléments explicites : correspondances entre texte et image, déroulement des étapes narratives, identification des personnages en présence et de leurs intentions. from the Fables de la Fontaine ${ }^{14}$ are not accompanied by the "real story." They are concerned that the children will only remember this "bad" or "wrong" version, and that they will "get confused." Similarly, the behaviour of the wolf, which, in the "complex" books, deviates from the traditional archetype, often leads these parents to fear that the child will get "lost" when these bearings are changed. They do not see this book as a game that allows the typical characteristics of the characters to be situated in relation to each other by implicitly comparing the archetypal wolf with the alternative one.

They use the clues in the pictures when they are referred to in the text (the flour that falls off the wolf's paw), but they do not do so when the relationship between text and image is merely implied. Instead of considering the brevity of the text as a sign that meanings must be found elsewhere, they consider this a sign of lower standards-the potential of these "complex" books is not mobilized. Indeed, even the explicit significations are curtailed by the adult for fear that the children will not understand books (both for "simple" texts and even more so for "complex" ones). These adults tend to "restrict" the book's meaning by "correcting" or adding to the reading, formulating the signification they have grasped and excluding other possibilities. The primary reading is seen as "exhausting" the significations of the text. These parents encourage their children in the cognitive activities of identifying and memorizing explicit elements such as the correspondence between the text and the pictures, the unfolding of narrative stages, and the recognition of characters and their intentions.

14 These Fables are a verse adaptation of Aesop's Fables published for the court of Louis XIV. They have been a shared reference for school children in France for several generations, used in reciting poetry as well as in moral education. The illustrated collections of these fables were among the first children's book accessible to all social classes. They have been progressively less used over the last twenty years due to increased competition from more contemporary children's books. 
À l'inverse, les parents du type 3 ont suivi des cursus d'études supérieures littéraires, artistiques ou pédagogiques et/ou exercent dans ces domaines professionnels : ces parents "cultivés" privilégient l'encouragement de l'enfant à formuler lui-même des non-dits, à former des hypothèses interprétatives en les justifiant à partir d'indices, et pas seulement à retenir les significations explicitées par le livre ou l'adulte. La lecture partagée est l'occasion de familiariser à des activités cognitives de recherche d'indices signifiants, de production d'anticipations sur la suite de l'histoire ou des conclusions de celle-ci. Elle constitue plus généralement une socialisation à une lecture qui est une enquête permanente sur le sens de l'ouvrage ou ses sens pluriels, où " lire » c'est construire des hypothèses de lecture, et les reformuler selon les indices découverts. Ces parents donnent à voir que des relectures du même ouvrage donnent accès à des significations complémentaires, voire différentes. Ces lectures partagées "savantes » sont particulièrement conduites lors de l'usage de l'album « complexe », mais ils comparent celui-ci et l'album patrimonial, et évoquent donc le conte. Par exemple, les loups des deux livres sont saisis comme occasion de faire ressortir les caractéristiques typiques, respectées ou détournées, de ce personnage. Et cette identification est désignée comme un indice permettant de comprendre une signification cachée de l'ouvrage. Cela est rendu possible notamment par la connaissance parentale de tous les récits auxquels il est fait allusion dans l'album " complexe ». Lire est ainsi exposé par le parent comme le fait de situer une œuvre dans un patrimoine et de prêter attention à une démarche de création : jouer avec les codes traditionnels, innover dans la manière de raconter, etc.

Mais ces familles du type 3 sont minoritaires, à la fois car les classes populaires sont majoritaires, mais aussi parce que d'autres familles de cadres et ingénieurs, au parcours moins marqué par la
Conversely, the parents in Type III have completed tertiary education in literature, arts, or education and/or are working in these professional areas. These "cultivated" parents focus on encouraging children to formulate the unspoken messages themselves, to elaborate interpretive hypotheses, and justify them using clues, as well as remembering the explicit significations presented by the book or the adult. Here shared reading is the opportunity to become familiar with cognitive activities involving the search for clues as to meaning, to produce anticipations as to the next stage of the story or its conclusions. More generally, it is a socialization to a form of reading based on a permanent quest for the meaning or meanings of a text, in which "reading" means constructing hypotheses and reformulating them according to the clues that are discovered. These parents show that rereading a given text provides access to complimentary, or even different, meanings. This "scholarly" shared reading is particularly common in the case of "complex" texts, but they also compare these texts to the more traditional versions and mention the original fairy tale. For example, the wolves in the two books are used to evoke the typical, respected, or distorted characteristics of this character. Moreover, this identification is presented as a clue to a hidden meaning in the complex text. This is made possible by the parents' familiarity with all the references that are alluded to in the "complex" picture book. Reading is therefore revealed by the parent to be an act that involves situating a book within a patrimonial context and paying attention to the way it was created-playing with traditional codes, innovating with narrative styles, and so forth.

However, these Type III families are in the minority, both because working-class families represent the majority, and because there are other families in which the parents are managers or engineers, 
culture artistique et lettrée que par la culture technique, ont moins souvent recours à ces manières de lire savantes et se trouvent en situation d'entre deux avec les familles populaires. Ces familles de cadres techniques et commerciaux (type 4) peuvent utiliser des indices discrets quand ils les perçoivent, mais leur manière de lire n'est pas focalisée sur la découverte de sens cachés.

Ici, ce sont les acquis de la sociologie des pratiques culturelles qui éclairent en retour la sociologie des apprentissages scolaires. En effet, cette observation des lectures permet de saisir comment les co-lecteurs du type 3 articulent les moments de lecture « participatifs » (Renard 2011) - par exemple quand ils se laissent prendre par l'émotion ou le suspens -, et des moments de déprise I distanciation, plus conforme au mode de lecture requis mais peu enseigné à l'Ecole. Ce sont ces moments d'étude et de rupture avec le flux du récit qui sont surtout appréhendés par la sociologie de l'école, qui laisse souvent dans l'ombre ce en quoi "l'étude " des œuvres participe en retour à leur appréciation en revanche " participative » (le repérage de telle figure de style contribuant à ce que certains élèves s'identifient aux ressentis, suspens ou contemplation, que le texte sollicite chez le "lecteur supposé »).

\subsection{Répertoires éclectiques, manières de lire homogènes ?}

Dans les familles du type 3 , la bibliothèque disponible contient des genres d'albums éclectiques quant à leur légitimité, et qui sollicitent une variété de formes d'activités cognitives. Mais les manières de lire dans ce même type de familles ne sont pas si dissonantes que ce que laisserait croire la diversité des albums présents. Car si des nuances existent dans la manière de lire les for example, whose trajectories are less marked by artistic and literary culture than by technical culture (Type IV). This type of family tends to mobilize these "scholarly" ways of reading less often and therefore finds itself in a kind of intermediary position between Types II and III. These families of technical and commercial managers may use subtle clues when they are aware of them, but their way of reading is not focused on the discovery of hidden meanings.

Here we can see that the gains of the sociology of cultural practices in turn shed light on the sociology of learning. Indeed, this observation of shared reading allows us to understand how co-readers in Type III articulate the moments of "participative reading" (Renard 2011)-for example when they are swept up in the emotion or the suspense-as well as moments in which they distance themselves from the text, which is more in keeping with the form of reading required, but not commonly taught at school. Sociologists of education are particularly interested in these moments of concentration or distance from the flow of the narrative, which often overlooks how the "study" of these texts participates in their "participative" appreciation (the identification of a particular figure of style may help some children identify with the feelings, suspense, or contemplations that the text provokes in the "supposed reader").

\subsection{Eclectic Repertoires, Homogenous Ways of Reading?}

In Type III families, the library available to children contains books that are eclectic in terms of their legitimacy, and which draw on a variety of kinds of cognitive activity. But reading practices in the same kind of families are not as dissonant as we might expect from the diversity of books present. Although there are nuances in the ways in which types of book might be read (the "traditional" 
deux albums (le « patrimonial » fait l'objet d'un moindre décodage car il le sollicite moins), les guidages par l'échange en plus du texte, les questions, les regards complices, insistants et silencieux qui invitent à chercher, etc. participent à une homogénéisation du regard à porter sur les livres : c'est une lecture savante qui est encouragée, menant l'enquête sur des significations possibles. C'est le cas dans le décodage de l'album « complexe », comparé avec l'album « patrimonial » mais aussi avec d'autres, et inscrit dans un répertoire culturel plus large. Cette homogénéité du regard intellectualisant porté sur les œuvres organise l'éclectisme apparent du répertoire.

Pour leur part, les familles populaires (types 1 et 2) montrent à la fois une univorité des genres d'albums lus (parmi les moins légitimes) et une relative homogénéité des modalités de lectures possibles (oralisation du texte pour le type 1, focalisation sur la signification explicite pour le type 2)

II y a une influence du support, qui encourage plus ou moins des lectures de différents niveaux (les écarts sont moindres entre les types de familles) avec l'album patrimonial qu'avec l'album complexe. Mais cette influence n'est donc que relative : les familles du type 3 mobilisent des activités cognitives assez peu répandues socialement qui sont celles que sollicitent les albums complexes, et elles le font aussi bien pour lire ceux-ci que pour lire les ouvrages patrimoniaux à la lumière des « complexes ». À l'inverse, les familles populaires (types 1 et 2) lisent tous les ouvrages avec les modalités qui leur sont habituelles pour lire les albums explicites. Une même œuvre peut donc être lue différemment : son appartenance à un répertoire plus ou moins légitime ne suffit pas à ce qu'on puisse déduire la lecture qui en sera faite. "L'éclectisme " apparent des répertoires (mesuré par le contenu de la bibliothèque domestique) est alors à nuancer par la relative cohérence des « manières de lire » des œuvres disparates. text is subject to less decoding because it requires less), parental guidance through discussion around the text, questions, shared glances, silence, and emphasis, which invite the child to look for themselves, all contribute to a homogenization of the way books are considered. For all kinds of books, it is intelligent reading that is encouraged -that which leads to the investigation of possible meanings. This is the case in the decoding of the "complex" book compared with the "traditional" book, but also for others, and is inscribed in a broader cultural repertoire. This homogeneity of the intellectualizing perspective on children's books brings order to the apparent eclecticism of the repertoire.

As for the working-class Type I and II families, they show both a univorous consumption of picture book genres (among the least legitimate) and a relative homogeneity in modalities of reading possible (vocalization of the text for Type I, emphasis on the explicit meanings for Type II).

The kind of text has an influence on this, with the traditional and the complex book more likely to encourage different levels of reading. But this influence is only relative. Type III families mobilize cognitive activities that are not very widespread socially, and they do so both in reading complex texts but also in reading the traditional books in contrast with them. Conversely, working-class families (Types I and II) read all the books in the same way as they read simple texts. A given picture book can thus be read in different ways. Whether it belongs to a more or less legitimate repertoire is not enough for us to be able to deduce the way it will be read. The apparent "eclecticism" of the repertoires (measured by the content of the home libraries) must therefore be considered in light of the relative coherence in the "ways of reading" these disparate works. 
De même, le fait qu'une famille populaire ait, isolé dans sa bibliothèque, un album « complexe », parce qu'il a été acquis par la rencontre ponctuelle d'un canal de diffusion légitime, ne suffit pas à ce que la lecture qu'elle en fait recoure aux principales et plurielles manières de lire que ce livre permet ou encourage. La légitimité d'une œuvre fréquentée n'implique pas mécaniquement son usage « légitime », ou plutôt « savant ».

\section{Conclusion}

Ces résultats confirment le choix de la recherche de s'intéresser aux activités cognitives : sans invalider les résultats les plus fréquents de la sociologie de la culture, ni leur interprétation théorique en termes d'omnivorité ou de légitimité, ils les déplacent en s'intéressant à la genèse de ces constats dans la socialisation culturelle enfantine, et ils invitent à étudier les activités socio-cognitives d'appropriation et d'appréciation chez les enfants comme chez les adultes.

Ce déplacement de la frontière de la sociologie de la culture emprunte ici d'abord à la sociologie de l'éducation. Inversement, les avancées de la sociologie de la culture en matière de compréhension de l'évolution de la légitimité culturelle, notamment de ses caractéristiques éclectiques, seraient bien utiles à la sociologie de l'éducation quand elle s'interroge sur les évolutions curriculaires et sur la reconnaissance du patrimoine culturel que

l'École a pour mission de transmettre.

Les emprunts qui ont été mis au service de la sociologie de la culture ont également été réalisés dans d'autres disciplines : didactiques, psychologie des apprentissages, études littéraires et narratologiques, histoire de la littérature. S'ils occasionnent quelques " coûts ", ils ont l'avantage de dégager de nouvelles
Similarly, the fact that a working-class family has a "complex" book in their library-possibly acquired through an unusual encounter with a legitimate channel of distribution-is not sufficient for the way it is read to mobilize the primary and secondary readings that it may encourage or require. The legitimacy of a work does not necessarily imply that it is used in "legitimate" or "intellectual" ways.

\section{Conclusion}

These results confirm the choice of this research to focus on cognitive activities. Without invalidating the most frequent results from the sociology of culture, nor their theoretical interpretation in terms of omnivorousness and legitimacy, we have shifted the focus by looking at the origins of these observations in childhood cultural socialization, and these results support the need for further study of the socio-cognitive activities involved in appropriation and appreciation both among children and adults.

This shift in the borders of the sociology of culture borrows above all from the sociology of education. On the other hand, advances in the sociology of culture in terms of understanding the evolution of cultural legitimacy, particularly in terms of its eclectic characteristics would be very useful for the sociology of education when it questions evolutions in curriculum and the recognition of the cultural heritage that schools aim to transmit.

The elements on loan to the sociology of culture here were also taken from other disciplines: didactics, psychology of learning, literary and narrative studies, and history of literature. Although they may incur certain "costs," they have the advantage of paving the way for new avenues of research in sociology. This approach, 
voies de recherche pour la sociologie. Cette démarche qui consiste à emprunter des résultats à d'autres disciplines pourrait également utile pour étudier les activités socio-cognitives que les êtres sociaux mobilisent dans d'autres domaines que la culture ou l'éducation.

Stéphane Bonnéry Université Paris 8/Centre interuniversitaire de recherche, culture, éducation, formation et travail, axe éducation et scolarisation (CIRCEFT- ESCOL)

\section{Références bibliographiques}

Bautier Élisabeth, Crinon Jacques, Delarue-Breton Catherine, Marin Brigitte (2012). "Les textes composites : des exigences de travail peu enseignées ? ». Repères, $45: 63-79$.

BAUTIER Élisabeth \& RAYOU Patrick (2009). Les Inégalités d'apprentissage. Paris, PUF.

BAUTIER Élisabeth \& RocheX Jean-Yves (2007) [1997]. « Apprendre : des malentendus qui font la différence ? ». In DeAUVIEAU Jérôme \& TERRAIL Jean-Pierre (dir.), Les Sociologues, l'école et la transmission des savoirs. Paris, La Dispute : 227-241.

Bernstein Basil (1975). Langage et classes sociales. Paris, Minuit.

BoIRON Véronique (2006). « Le développement de l'enfant apprentiinterprète : interactions adulte-texte-enfants à l'école maternelle ». Les dossiers des Sciences de /Éducation, $15: 11-25$.

BONNÉRY Stéphane (2007). Comprendre l'échec scolaire. Paris, La Dispute.

BONNÉRY Stéphane (2012). « Les outils sémiotiques et les dispositions sollicitées : sociologie historique des "lecteurs supposés" dans le Père which consists in borrowing results from other disciplines, could also prove useful for studying the socio-cognitive activities that social beings mobilize in areas other than culture or education.

Stéphane Bonnéry

Université Paris 8/Centre interuniversitaire de recherche, culture, éducation, formation et travail, axe éducation et scolarisation (CIRCEFT- ESCOL)

\section{References}

Bautier Élisabeth, Crinon Jacques, Delarue-Breton Catherine, MariN Brigitte (2012). "Les textes composites: des exigences de travail peu enseignées ?." Repères, 45: 63-79.

BAUTIER Élisabeth \& RAYOU Patrick (2009). Les Inégalités d'apprentissage. Paris, PUF.

BAUTIER Élisabeth \& RocheX Jean-Yves (2007) [1997]. "Apprendre: des malentendus qui font la différence ?." In DEAUVIEAU Jérôme \& TERRAIL Jean-Pierre (eds.). Les Sociologues, l'école et la transmission des savoirs. Paris, La Dispute: 227-241.

Bernstein Basil (1975). Langage et classes sociales. Paris, Minuit.

BOIRON Véronique (2006). "Le développement de l'enfant apprentiinterprète: interactions adulte-texte-enfants à l'école maternelle." Les dossiers des Sciences de l'Education, 15: 11-25.

BonNÉRY Stéphane (2007). Comprendre l'échec scolaire. Paris, La Dispute.

BONNÉRY Stéphane (2012). "Les outils sémiotiques et les dispositions sollicitées: sociologie historique des "lecteurs supposés" dans le Père 
Castor (Premières lectures) et la littérature enfantine ». Séminaire Paul Faucher (1898-1967) : l'édition au service de l'Education nouvelle (Dynadiv, Ciciic et Circeft, les Amis du Père Castor). [En ligne] : http:// halshs.archives-ouvertes.fr/halshs-00684257 [consulté le 23 février 2018].

BonNÉRY Stéphane (2014). « Les livres et les manières de lire à l'école et dans les familles : réflexions à l'occasion de la parution de la liste "maternelle" ». Le français aujourd'hui, 185 : 47-57.

BONNÉRY Stéphane \& ELOY Florence (2018). « La socialisation à la "disposition esthétique"' dans l'enseignement musical : un analyseur des modalités légitimes d'organisation de l'éclectique ». In KIRSCHBERG Irina \& RoBert Alexandre (dir.), Bourdieu et la musique. Bilan et perspectives. Paris, Delatour (à paraître).

Bourdieu Pierre, Darbel Alain, Schnapper Dominique (1966). L'Amour de l'art. Paris, Minuit.

Bourdieu Pierre \& Passeron Jean-Claude (1964). Les Héritiers. Paris, Minuit.

BouRdieu Pierre (1979). La Distinction. Critique sociale du jugement. Paris, Minuit.

BOURDIEU Pierre (1997). Méditations pascaliennes. Paris, Seuil.

ChAmBoredon Jean-Claude (1985). « Une sociologie de la petite enfance? ». Espaces Temps, 31/32: 85-90.

ChAmBoredon Jean-Claude \& FABIANI Jean-Louis (1977). « Les albums pour enfants. Le champ de l'édition et les définitions sociales de l'enfance ». Actes de la recherche en sciences sociales, $13: 60-78$ et $14: 55-79$.
Castor (Premières lectures) et la littérature enfantine." Séminaire Paul Faucher (1898-1967): l'édition au service de l'Education nouvelle (Dynadiv, Ciciic et Circeft, les Amis du Père Castor). [On line]: http:// halshs.archives-ouvertes.fr/halshs-00684257 [accessed on 2 Februar 2018].

BONNÉRY Stéphane (2014). "Les livres et les manières de lire à l'école et dans les familles: réflexions à l'occasion de la parution de la liste 'maternelle'." Le français aujourd'hui, 185: 47-57.

BONNÉRY Stéphane \& ELOY Florence (2018). "La socialisation à la 'disposition esthétique' dans l'enseignement musical: un analyseur des modalités légitimes d'organisation de l'éclectique." In KIRSCHBERG Irina \& RoBert Alexandre (eds.). Bourdieu et la musique. Bilan et perspectives. Paris, Delatour (à paraître).

Bourdieu Pierre, Darbel Alain, Schnapper Dominique (1991) [1966]. The Love of Art: European Art Museums and Their Public. English translation by Caroline Beattie and Nick Merriman. Palo Alto, Stanford University Press.

BOURDIEU Pierre \& PASSERON Jean-Claude (1979) [1964]. The Inheritors. English translation by Richard Nice. Chicago, University of Chicago Press.

BouRdieU Pierre (1984) [1979]. Distinction. A Social Critique of a Judgement of Taste. English translation by Richard Nice. London/New York, Routledge.

BouRdieu Pierre (2000) [1997]. Pascalian Meditations. English translation by Richard Nice. Palo Alto, Stanford University Press.

Chamboredon Jean-Claude (1985). "Une sociologie de la petite enfance ?." Espaces Temps, 31/32: 85-90.

Chamboredon Jean-Claude \& FABIANI Jean-Louis (1977). "Les albums pour enfants. Le champ de l'édition et les définitions sociales de l'enfance." Actes de la recherche en sciences sociales, 13:60-78 et 14:55-79. 
ChARTIER Anne-Marie (2009). « Lire avec les enfants ». Le Point sur..., $14: 3-8$.

ChARTIER Anne-Marie \& HÉbrard Jean (2000). Discours sur la lecture (1880-2000). Paris, BPI-Centre Pompidou/Fayard.

Connan-PINTADo Christiane (2010). Lire des contes détournés à l'école. Paris, Hatier.

CoUlANGEON Philippe (2004). «Classes sociales, pratiques culturelles et styles de vie. Le modèle de la distinction est-il (vraiment) obsolète ? ». Sociologie et sociétés, 36(1) : 59-85.

DARMON Muriel (2010). La Socialisation. Paris, Armand Colin, $2^{\mathrm{e}}$ édition.

DÉTREZ Christine (1998). Finie, la lecture ? Lire au collège, lire au lycée. Une enquête longitudinale (Thèse de doctorat en sociologie). Paris, EHESS.

Donnat Olivier (1994). Les Français face à la culture. De l'exclusion à l'éclectisme. Paris, La Documentation française.

ELoY Florence (2015). L'Enseignement de la musique au collège. Cultures juvéniles et culture scolaire. Paris, PUF.

EWERS Hans-Eino (1996). « La littérature moderne pour enfants : son évolution historique à travers l'exemple allemand du XVIII $\mathrm{au} x \mathrm{X}^{\mathrm{e}}$ siècle ». In BECCHI Egle \& JULIA Dominique (dir.). Histoire de l'enfance en Occident. Tome 2. Paris, Points Seuil : 457-483.

FABIANI Jean-Louis (2013). « Distinction, légitimité et classe sociale ». In COULANGEON Philippe \& DUVAL Julien (dir.). Trente ans après la distinction. Paris, La Découverte : 69-82.
Chartier Anne-Marie (2009). "Lire avec les enfants." Le Point sur..., 14: 3-8.

Chartier Anne-Marie \& HÉBrard Jean (2000). Discours sur la lecture (1880-2000). Paris, BPI-Centre Pompidou/Fayard.

Connan-PInTADo Christiane (2010). Lire des contes détournés à l'école. Paris, Hatier.

CoulANGEON Philippe (2004). "Classes sociales, pratiques culturelles et styles de vie. Le modèle de la distinction est-il (vraiment) obsolète ?." Sociologie et sociétés, 36(1): 59-85.

DARMON Muriel (2010). La Socialisation. Paris, Armand Colin, $2^{\mathrm{e}}$ édition.

DÉTREZ Christine (1998). Finie, la lecture ? Lire au collège, lire au lycée. Une enquête longitudinale (PhD dissertation, Sociology). Paris, EHESS.

Donnat Olivier (1994). Les Français face à la culture. De l'exclusion à l'éclectisme. Paris, La Documentation française.

ELoY Florence (2015). L'Enseignement de la musique au collège. Cultures juvéniles et culture scolaire. Paris, PUF.

EWERS Hans-Eino (1996). "La littérature moderne pour enfants: son évolution historique à travers l'exemple allemand du $x \mathrm{VIII}{ }^{\mathrm{e}} \mathrm{au} x \mathrm{XX}^{\mathrm{e}}$ siècle." In BECCHI Egle \& JULIA Dominique (eds.). Histoire de l'enfance en Occident. Tome 2. Paris, Points Seuil: 457-483.

FABIANI Jean-Louis (2013). "Distinction, légitimité et classe sociale." In COULANGEON Philippe \& DUVAL Julien (eds.). Trente ans après la distinction. Paris, La Découverte: 69-82. 
Glevarec Hervé \& PINET Michel (2009). " La "tablature" des goûts musicaux : un modèle de structuration des préférences et jugements ». Revue française de sociologie, 50(3) : 599-640.

Grossmann Francis (1996). Enfances de la lecture. Manières de faire, manières de lire à l'école maternelle. Berne, Peter Lang.

ISAMBERT-JAMATI Viviane (2005). «Approches sociologiques des contenus d'enseignement ». In RAMOgnino Nicole \& Vergès Pierrette (dir.). Le Français hier et aujourd'hui. Aix-en-Provence, Presses universitaires de Provence : $19-36$

KAKPO Séverine (2012). Les Devoirs à la maison. Mobilisation et désorientation des familles populaires. Paris, PUF.

LAHIRE Bernard (1993). La Raison des plus faibles. Lille, Presses universitaires de Lille.

LAHIRE Bernard (1995). Tableaux de familles. Paris, Gallimard/Seuil.

LAHIRE Bernard (2002). Portraits sociologiques. Paris, Nathan.

LAHIRE Bernard (2006). La Culture des individus. Dissonances culturelles et distinction de soi. Paris, La Découverte/Poche.

LAHIRE Bernard (2012). « Des effets délétères de la division scientifique du travail sur l'évolution de la sociologie ». SociologieS. [En ligne] http:// sociologies.revues.org/3799 [consulté le 23 février 2018].

LIENARD Georges \& SERVAIS Émile (1976). Le Capital culturel : déterminants sociaux et stratégies de transmission. Bruxelles, Vie ouvrière.

MAUGER Gérard (1999). «Écrits, lecteurs, lectures ». Genèses, 34 : 144161.
Glevarec Hervé \& Pinet Michel (2009). "La 'tablature' des goûts musicaux: un modèle de structuration des préférences et jugements." Revue française de sociologie, 50(3): 599-640.

Grossmann Francis (1996). Enfances de la lecture. Manières de faire, manières de lire à l'école maternelle. Berne, Peter Lang.

ISAMBERT-JAMATI Viviane (2005). "Approches sociologiques des contenus d'enseignement." In Ramognino Nicole \& Vergès Pierrette (eds.). Le Français hier et aujourd'hui. Aix-en-Provence, Presses universitaires de Provence: 19-36.

KAKPO Séverine (2012). Les Devoirs à la maison. Mobilisation et désorientation des familles populaires. Paris, PUF.

LAHIRE Bernard (1993). La Raison des plus faibles. Lille, Presses universitaires de Lille.

LAHIRE Bernard (1995). Tableaux de familles. Paris, Gallimard/Seuil.

LAHIRE Bernard (2002). Portraits sociologiques. Paris, Nathan.

LAHIRE Bernard (2006). La Culture des individus. Dissonances culturelles et distinction de soi. Paris, La Découverte/Poche.

LAHIRE Bernard (2012). "Des effets délétères de la division scientifique du travail sur l'évolution de la sociologie." SociologieS. [On line] http:// sociologies.revues.org/3799 [accessed on 23 February 2018].

LIENARD Georges \& SeRVAIs Émile (1976). Le Capital culturel: déterminants sociaux et stratégies de transmission. Bruxelles, Vie ouvrière.

MAUGER Gérard (1999). "Écrits, lecteurs, lectures.” Genèses, 34: 144-161. 
MAuss Marcel (1950) [1924]. « Rapports réels et pratiques de la psychologie et de la sociologie ». In MAuss Marcel, Sociologie et anthropologie. Paris, PUF

Nières-CheVRel Isabelle (2009). Introduction à la littérature de jeunesse. Paris, Didier Jeunesse.

Octobre Sylvie, Détrez Christine, Mercklé Pierre, Berthomier Nathalie (2010). L'Enfance des loisirs. Trajectoires communes et parcours individuels à la fin de l'enfance et à la grande adolescence. Paris, MCCDEPS/La Documentation française.

PAsquier Dominique (2005). Cultures lycéennes : la tyrannie de la majorité. Paris, Autrement.

PASSERON Jean-Claude (1991). "Les trois savoirs sur le savoir. Sociologie et sciences de l'éducation ». Le Raisonnement sociologique. Paris, Nathan : 347-354.

Peterson Richard (2004). "Le passage à des goûts omnivores : notions, faits et perspectives ». Sociologie et sociétés, 36(1) : 145-164.

Renard Fanny (2011). Les Lycéens et la lecture. Entre habitudes et sollicitations. Rennes, Presses universitaires de Rennes.

ROCHEX Jean-Yves (2009). « Repenser l'une par l'autre exigence de culture et exigence de justice sociale : vers une sociologie du développement cognitif ? ». In Derouet Jean-Louis \& Derouet-Besson Marie-Claude. Repenser la justice dans le domaine de l'éducation et de la formation. Paris, INPR : 105-116.

RocheX Jean-Yves \& CRINon Jacques (dir.) (2011). La Construction des inégalités scolaires au cœur des pratiques et dispositifs d'enseignement. Rennes, Presses universitaires de Rennes.
MAuss Marcel (1950) [1924]. "Rapports réels et pratiques de la psychologie et de la sociologie." In Mauss Marcel, Sociologie et anthropologie. Paris, PUF.

Nières-CheVReL Isabelle (2009). Introduction à la littérature de jeunesse. Paris, Didier Jeunesse.

Octobre Sylvie, Détrez Christine, Mercklé Pierre, Berthomier Nathalie (2010). L'Enfance des loisirs. Trajectoires communes et parcours individuels à la fin de l'enfance et à la grande adolescence. Paris, MCCDEPS/La Documentation française.

PASQUIER Dominique (2005). Cultures lycéennes: la tyrannie de la majorité. Paris, Autrement.

PASSERON Jean-Claude (1991). "Les trois savoirs sur le savoir. Sociologie et sciences de l'éducation." Le Raisonnement sociologique. Paris, Nathan: 347-354.

PETERSON Richard (2004). "Le passage à des goûts omnivores: notions, faits et perspectives." Sociologie et sociétés, 36(1): 145-164.

Renard Fanny (2011). Les Lycéens et la lecture. Entre habitudes et sollicitations. Rennes, Presses universitaires de Rennes.

Rochex Jean-Yves (2009). "Repenser l'une par l'autre exigence de culture et exigence de justice sociale: vers une sociologie du développement cognitif ?." In Derouet Jean-Louis \& Derouet-Besson Marie-Claude. Repenser la justice dans le domaine de l'éducation et de la formation. Paris, INPR: 105-116.

Rochex Jean-Yves \& Crinon Jacques (eds.) (2011). La Construction des inégalités scolaires au ccur des pratiques et dispositifs d'enseignement. Rennes, Presses universitaires de Rennes. 